\title{
Pre-Service Teachers' Reflection Logs: Pieces of Evidence of Transformative Teaching and Emancipation
}

\author{
Jasper Jay Nievera Mendoza, Ph.D. ${ }^{1}$ \\ ${ }^{1}$ Tarlac State University, College of Teacher Education, Lucinda Campus, Tarlac City, Philippines \\ Correspondence: Jasper Jay Nievera Mendoza, Ph.D., Tarlac State University, College of Teacher Education, \\ Lucinda Campus, Tarlac City, Philippines. E-mail: jjn.mendoza@tsu.edu.ph
}

Received: July 28, 2020

Accepted: September 21, 2020

Online Published: September 22, 2020

doi:10.5430/ijhe.v9n6p200

URL: https://doi.org/10.5430/ijhe.v9n6p200

\begin{abstract}
With critical social design put into practice, this study described and investigated transformative teaching and emancipation pieces of evidence from 21 Music, Arts, Physical Education and Health (MAPEH) pre-service teachers. The participants' reflection logs were analyzed, with Butin's technical lens framework as a guide. Findings revealed that the pre-service teachers encountered challenges with the students, parents, cooperating teachers and principals, which turned out to be opportunities for pre-service teachers to exercise their decision-making skills. These participants' springboard to transformative learning and emancipation, henceforth, were the teaching strategies, principles and learning activities they acquired from their instructors. Pre-service teachers realized they could explore epistemic change as a result of reflection and contemplation.
\end{abstract}

Keywords: MAPEH, pre-service teachers, emancipation, transformative learning, feflection logs

\section{Introduction}

\subsection{Background}

In the classroom, teachers have the responsibility and accountability to tap the talents and potentials of learners so that they are properly guided and ushered in achieving the best that they could be. They can choose from a wide range of methodologies, strategies, and techniques to transfer learning successfully (Adebola, Tsotetsi \& Omodan, 2020; Hong, 2020; Jafri, Manaf \& Razali, 2020; Mondal, 2015; Parrett \& Budge, 2020; Sorensen \& Robertson, 2019; Utemov, 2019).

Teachers are also provided with teaching and learning theories which would guide them as they embark on their journey with the learners towards engagement, enlightenment, empowerment, productivity, competence, and excellence (Abdullah et al., 2020; Doğan \& Yurtseven, 2018; Huong et al. 2020; Littky \& Grabelle, 2012; Liu \& Liao, 2019; Nool, 2012; Özdemir, 2020; Qadhi et al., 2020; Rahiem, Abdullah \& Krauss, 2020; Sela-Shayovitz \& Finkelstein, 2020). Likewise, teachers need to choose appropriate theories to suit the learning needs of the students (Zhang, Kuusisto \& Tirri, 2020). Accordingly, several theories of learning were believed to be effective in teaching students and in acquiring competencies effectively. Transformative learning is one of those innumerable theories.

However, education must go beyond current theories and principles in order to be functional and meaningful. Just as technology has dramatically inflicted change in the processes and services of the world, education must also be essentially innovative in order to cope with these changes in the society. It must be in touch with the actual environment to provide practical and functional teaching and learning to the point that students no longer need to wait after graduation and employment to apply what they learned, but are able to make sense of their classroom learning and use what they learned to solve their daily problems.

The experience of the researcher as a classroom instructor and supervisor has made him realize that teachers must exert more effort in providing meaningful learning. He encountered some pre-service teachers who tried to manage learning based on available theories without thorough reflection of the students' circumstances. This results to rote learning or the students' tendency to just store the information in their memory and soon forget it after an examination.

Pre-service education must teach students to be smart, resilient, and reflective so that they can address the pressing needs of the learners that they handle. They have to be transformative rather than prescriptive. As such, a prescriptive 
teacher limits the learners to ideals and norms. On the other hand, a transformative teacher broadens the learners' horizons and considers other alternatives that are potential and practical in solving problems.

Transformative learning is one of the theories that emerged because of the work of Jack Mezirow (1981, 1991 and 1997). During the time of Mezirow (1981), adult learning focused primarily on mastering the basic skills but he thought that adult learning must be transformative. According to him, this style of learning would enable the adults to recognize and reassess the structure of assumptions and expectations, which frame their thinking, action and feeling rather than acquiring only basic skills. Transformational learning has a unique feature of inducing far-reaching change in the learner, such as using learning experiences to shape and to develop a learner and to produce significant impact that would in turn determine subsequent learning experiences (Khabanyane, et al., 2014).

Transformational learning involves three dimensions, namely: psychological (changes in understanding self), convictional (revision of self of belief systems), and behavioral (changes in lifestyles). This entails critical understanding of oneself-knowing what one has and what he does not have, identifying what is still lacking or what needs modification, recognizing the need to reinvent beliefs and value systems until things become part of lifestyle (Kitchenham, 2008). More so, in transformative learning, the need for reflection is very important. Learners have to regard themselves as adults capable of self-introspection; learners need to make sense of their experiences and interpret them. Reflections enable learners to correct distortions of existing beliefs and embrace new value system as a result of experience (Mizerow, 2011).

As such, reflections lead to transformative learning. In other words, learners have to re-evaluate their lives and remake them. Through reflective thinking, adults develop their own set of strategies coming up with solutions to their problems. Their experiences in classroom or outside the classroom would enable them to think and analyze the relevant and irrelevant, which in turn will shape a new paradigm of doing things.

Reflective or critical thinking, as an arm of transformational learning, is also one of the learning skills that the $\mathrm{K}$ to 12 curriculum envisions to develop among the 21 st century learners along with creativity and innovation, problem solving, communication, and collaboration (Department of Education, 2012; De Dios, 2012). These skills are believed to be important in achieving functional literacy in the society. This would bolster the need to utilize transformative learning theory in the classroom, not only in the tertiary level but also as early as in basic educational ladders as well.

One of the best avenues to use transformative learning is during pre-service teaching. In this phase, students are exposed in the field for them to experience actual classroom environment under the guidance and mentorship of cooperative teachers. Pre-service teaching is vital in developing student teachers' technical, pedagogical and content competencies (Hu and Fyfe, 2010; Mergler, 2012) since they are exposed to real-life experiences with learners, teachers, parents and other school stakeholders. Students have the opportunity to handle actual classes and are expected to apply learning theories, classroom management strategies, teaching methods and instructional strategies which they learned under the auspices of their college professors (Corpuz, et al., 2006). Ergo, pre-service teaching reinforces classroom learning which clearly indicates that students still continue to acquire teaching competencies in their experiential exposure. This training would help them muster classroom management (Freeman, et al., 2014), which is the focus of the teaching profession.

However, an actual field teaching may challenge pre-service teachers' knowledge schema, skills and attitude. It can make pre-service teachers realize that principles and theories which they learned in their principles of teaching class, may not be applicable to some learners as echoed by Zeichner (2010) in his study. He concluded that the old paradigm of university-based teacher education where academic knowledge is viewed as the authoritative source of knowledge about teaching needs to change to one where there is a nonhierarchical interplay between academic, practitioner, and community expertise. This is true today given the fact that children are born in a world where technology has changed the landscape of how things are done and how they acquire information. Gone are the days that students just rely on their teachers for new information. Access to information is just a fingertip away for children who, at their tender age, can use gadgets more efficiently than their parents or grandparents. Teachers must cope with this turn of events in information-dissemination.

This new philosophy of teacher education will better prepare pre-service teachers in enacting complex teaching practices. They must be alert to take the lead and complement what learners know in order to make classroom learning meaningful and rewarding.

In the Philippines, pre-service teaching is given utmost attention (Teaching Council, 2011; Department of Education, 2005; Commission on Higher Education, 2009) because of the wide opportunities and rich experiences that prepare 
them to meet the challenges in the real learning environment.

As these pre-service teachers go to the field, they would be encountering learners with diverse needs. They would also be confronted with problems such as inadequacies of teaching resources, which is one of the problems besetting public schools in the Philippines, and curricular changes like the $\mathrm{K}$ to 12 curriculum, which they had not learned in their classrooms (Ortilla, 2015). The researcher was a part of a team who were upskilled to train DepED teachers in the implementation of the $\mathrm{K}$ to 12 curriculum. He observed the need for resources and extensive training in order to carry out the lessons following standard guidelines. He also saw the need to train pre-service teachers to fully prepare them for the work ahead. Because of the new curriculum, processes and procedures in teaching and learning in classroom would be different from the actual situation. The changes had necessitated mass trainings for teachers and school heads because the tools which they acquired may no longer be useful once they implement the K to 12 curriculum (Official Gazette, 2012).

This study was therefore conceptualized to help enrich the field exposure of MAPEH pre-service teachers in Region 3 . The changes brought about by the $\mathrm{K}$ to 12 Curriculum and changes in the communities brought about by technology should not derail the confidence of the pre-service teachers in the actual field. They can only do this if their training enables them to acquire the skills to be resilient and transformative in their approach in the actual field. The initial tool to possess resiliency and transformative teaching is to be observant and reflective of the learners and their learning environment. Using critical thinking, they are expected to design teaching that meet the learning needs of the students and equip them with skills to confront their daily problems to their advantage.

This study then was an attempt to look into how MAPEH teachers use their reflection logs in planning and executing teaching and learning using technical lens of Butin's model. Specifically, it delved into the reflective logs of the pre-service teachers from selected Teacher Education Institutions (TEIs), which offered BSED in MAPEH particularly and had acquired at least Level III accreditation make decisions in teaching-learning situation, of which the goal is effective transfer of learning competencies.

\subsection{Framework of the Study}

Pre-service teaching requires critical thinking. Pre-service teachers have to analyze classroom scenarios vis-à-vis theories acquired and act on events accordingly. At some point, they may need to vary their approaches depending on the situation.

Critical social theory is a school of thought that stresses reflective assessments and critique of society and culture by applying knowledge from the social sciences and humanities (Corradetti, 2015). This theory was pioneered by Marx and Freud when they started to criticize capitalism as an economic ideology. They strongly criticized the oppression of the working group by the capitalists. They opined that only when the working group rises against the dominant groups can liberation of the oppressed be achieved (Seiler, 1988). Critical theorists believed that examining social conditions would uncover hidden structures. They believed that knowledge is power. When one understands that he is being oppressed, this understanding propels him to take action in order to change the situation.

In education, critical social theory has influenced radical changes in curriculum and pedagogy over the years (De Leon \& Ross, 2010). Prominent theorists who are members of the Frankfurt School such as Max Horkheimer (1895-1973), Theodore Adorno (1903-1969), and Herbert Marcuse (1898-1979) introduced upheavals in educational thoughts and systems (Jessop, 2012). There are more waves of theorists and philosophers who embraced the critical theory in their attempt to impose changes in education. The most prominent among the second-generation critical theorists is Jurgen Habermas whose theory of communicative action is receiving increasing attention in education theory and is of great importance to anyone seeking to understand and defend the role of schools in developing democratic values and practice (Bolton, 2005). In addition, critical pedagogy, a term coined by Henry Giroux in 1983, has its origins in Critical Theory and describes the work of theorists and practitioners alike that has an emancipatory orientation (Guilherme, 2010). Hudson (2014) holds that Giroux's critical pedagogy elaborated the philosophical foundations for a theory and practice of education that would be not only critical of established institutions and practices but also capable of transforming those institutions and practices, with the ultimate goal of transforming society itself.

The arm of critical learning theory and social learning is reflective thinking. Through reflections, an individual could analyze events and derive logical conclusions. According to Carrington and Selva (2010), reflective practice can and should be explicit, direct, thoughtful and patient, using personal reflection-in-action, to interpret one's service, reaction and dealings with people.

In teaching, the role of reflective thinking in the search for quality and relevant outputs is paramount. Teachers could 
use their reflections to transform learning. As emphasized by Facun and Nool (2012), teachers have to reflect on their ways of teaching the concepts to children. Through critical social theory in education, quality is proportional to the depth of analysis that teachers and students have at their disposal (Makam, 2012).

The 21st century teachers are urged to mold critical thinkers in order to confront issues surrounding them (Smith, 2014). Dewey, the theorist who revolutionized educational strategies through his modern views of what teaching and learning must be, suggested that reflective thinking is an active, persistent, and careful consideration of a belief or supposed form of knowledge, of the grounds that support knowledge, and the further conclusions to which that knowledge leads (Reflective Thinking, 2012). Poyraz and Usta (2013) investigated the reflective thinking tendencies of 449 preservice teachers who studied in various public institutions in Istanbul. Reflective thinking would make more sense in teaching rather than acquiring merely acquiring pieces of information. Meaningful learning is anchored on processing, transforming and reproducing information acquired appropriate in a given classroom environment. The findings of the study conducted showed that reflective thinking abilities of the participants were varied with respect to the growing up place and gender. The present study also delved into the reflection logs of 21 pre-service teachers to determine evidence of transformative learning and emancipation in their actual classroom teaching experience.

Furthermore, recognizing the importance of reflective journals in teaching, Yasin, Rahman and Ahmad (2012) developed and validated a framework for reflective learning using portfolios. The framework included rubric to evaluate the reflections of students in the portfolios. It is then imperative that teachers have to guide students in reflective thinking, which is an arm of critical social learning theory. As part of classroom requirements, reflective thinking should be encouraged by the teachers and should be used by the students to make sense of their classroom activities and write them in diaries or journals (Aquino \& Nool, 2018). Lee (2005) suggested that reflections depend upon interplay of factors which include personal background, field experience contexts, and the mode of communication. Reflections must be evaluated based on content and depth.

Even so, Butin (2006) developed a ruler to evaluate teachers' journals or reflection logs based on four lenses. Technical lens is a technical conceptualization of real-world learning that focuses on its pedagogical effectiveness. This involves the reflection of the pre-service teachers on pedagogical effectiveness of their experiences and how their exposure in their affiliation has enhanced the competencies they have learned from their teachers in their classrooms.

The Butin's model was used in the study of Tangen et al., (2011) when they explored the developing intercultural competence of Australian pre-service teachers. The written reflection logs of pre-service teachers were analyzed using four lenses. They were challenged by the presence or inclusion of non-Australian students until they were able to project how they could take their new understandings into the classrooms as inclusive teachers. Likewise, Butin's technical lens was used in analyzing the reflection logs of the MAPEH pre-service teachers.

Bean and Stevens (2002) explored the use of scaffolded reflection in two literacy education courses in an urban university in the southwestern United States. Through constant comparative and critical discourse analyses of on-line and written reflections, it was found that scaffolded reflections helped the students to formulate and articulate their personal belief system into teaching.

\subsection{Objective of the Study}

This study aimed to describe and investigate transformative teaching and emancipation pieces of evidence from MAPEH preservice teachers' reflection logs using Butin's technical lens framework as a guide.

\section{Method}

\subsection{Research Design}

This study adopted the critical social design in analyzing and integrating all the components of the study and data to address the research objective. The aim of critical social research is the concept that knowledge is constructed by current sets of social interactions (Harvery, 1990). Data gathered from the reflection logs of the participants were based on their classroom experiences. Knowledge was then generated on how MAPEH pre-service teachers use reflections in enhancing their pedagogical competencies and exercise transformational teaching.

\subsection{Participants and Setting}

This study delved into the reflection logs of select pre-service teachers in Music, Arts, Physical Education and Health who were exposed in partner schools to carry out their experiential learning. Reflection logs of 21 students (three from each TEI) in their prescribed field study books were analyzed. The study participants were selected based on 
maximum variation sampling. This technique of sampling enabled the selection of conservative number of participants which maximized the representation or diversity relevant to the research questions (Robert Wood Johnson Foundation, 2008). Seven of the students represented the best pre-service students (one from each TEI); seven came from the average cluster (one also from each TEI); and another seven represented the bottom cluster (one from each TEI). The researcher asked the supervisors in each school to recommend their exemplary pre-service teachers, the average, and bottom performers based on their General Weighted Average (GWA). The researcher believed that the supervisors from the respective schools knew their participants' academic performance so their recommendations were considered in the selection of study participants. The small number of participants enabled thorough analysis of their reflection logs in order to yield rich conclusions. Participants represented the slow, average and best learners in order to achieve balance in the analysis of the problem at hand.

To maintain anonymity of participants, their names were not reflected in their logs. Only their numbers were indicated in their reflection logs. The researcher selected 21 MAPEH pre-service teachers from seven Teacher Education Institutions in Region 3 as his participants.

\subsection{Sources of Data}

The main sources of data were the reflection logs (based on the questions from the Experiential Handbooks) of the participants. They answered the questions in their handbooks which detailed their pre-service experiences. According to Thomas, Nelson and Silverman (2010), qualitative data recording devices include notebooks, narrative field logs, and diaries, in which researchers record their reactions, concerns, and speculations.

Moreover, aside from the questions in the handbook, other questions were also included which served as scaffolds or guides in eliciting reflections that showed how the participants addressed diversity in class, political pressures and their realizations during their pre-service teaching exposure. These additional questions were crafted by the researcher which enabled the participants to share their experiences in handling cultural diversity and pressures from stakeholders such as parents, cooperating teachers and principals. These questions were essential in extracting their thoughts and how they had resolved pressures. These are key elements in transformational teaching.

The additional questions were framed in such a way that they had to dig deeper into their thoughts and their realizations that norms may differ considering school environments and principles, philosophies, techniques, methods and these may be modified in some aspects, upheld in other areas, or totally look for new ways of approaching educational confrontations. The reflection logs of some preservice teachers showed their realizations and their attempts to be transform pedagogies. These were the indicators of their teaching emancipation which emanated from their actual field exposure.

Furthermore, interviews were conducted with some of the participants to ensure that the researcher captured the participants' thoughts. The researcher arranged a schedule of interview with the supervisors. The said interview had extracted substantial information which deepened the researcher's understanding of the reflections from the participants' logs. The interview was deemed necessary to clarify short reflections from some of the participants especially since the researcher observed some participants' responses which were substantial but were only presented in bullet forms or phrases. Lastly, the researcher also conducted actual observation with three participants whom he supervised during their pre-service teaching.

\subsection{Data Collection Procedure}

The researcher sought permission to conduct the study from the presidents of the TEIs where the study was conducted. Upon approval, the deans were approached in order to arrange meeting with the participants. The researcher oriented them about the study and sought their consent. Upon approval, the participants were asked to reproduce their Experiential Handbooks after writing their journals on a weekly basis. For the additional questions, participants wrote their reflections on a separate paper. All in all, there were 19 questions which the participants answered. Five questions were from the handbook and the 14 were crafted by the researcher.

Data from the reflection logs of the participants were gathered. The coverage of the journal was from Week 1 of their exposure up to the end week during the Second Semester, AY 2015-2016. These reflection logs were analyzed by the researcher using Butin's framework. To validate the researchers' analyses, he sought the help of two experts. As a result, themes were extracted from the participants' reflections. Based on the themes extracted, a framework for pre-service teaching was developed in this study. 


\subsection{Data Analysis}

Qualitative data analysis techniques were employed in the study. In extracting themes from the participants' reflections, the researcher tabulated all the reflections by question to enable the use of constant comparison technique in analyzing qualitative data (such as the participants' reflections in this study). The tabulation was facilitated by a general matrix in which column 1 contained the participants' codes.

In coding, the researcher assigned capital letter alphabets to represent the school of the participants and Hindu-Arabic numerical was assigned to the corresponding individual participant. For example, A1 would represent participant 1 from the best pre-service teachers out of seven participants from each school; B1 would represent second participant from the average cluster in the same school; A2 was the participant from the best pre-service teacher from the second school and so on. The capital letter alphabets represented the best, average and bottom clusters, while the Hindu-Arabic numerals represented the schools. Further, Columns 2 to 20 of the matrix contained the participants' answers to 19 questions. The last column encapsulated the researcher's notes and decisions on the responses to be classified under technical lens.

The matrix contained five columns. Column 1 reflected the codes of the participants. The second column showcased the participants' verbatim reflections. The third column shouldered the formulated meanings based on the analysis of the researcher. Fourth column contained the concept elicited and the last column is the theme generated. To put it simply, columns 3-5 were based on the researcher's interpretations.

Guided by technical lens of Butin's model, the researcher generated categories or themes (using thematic analysis) by constantly checking the emergent understandings and clarifying these with two experts. The first expert is a director of Physical Education and supervisor of experiential learning in a reputable university in the National Capital Region. The other expert is also a supervisor in experiential learning and holds an undergraduate degree Bachelor of Science in Physical Education and Graduate Degrees-Master of Arts in Teaching Physical Education and Doctor in Philosophy in Educational Leadership.

According to Stemler (2002), two people must independently review materials for their content and come up with a set of features. The purpose of engaging expert evaluators was to avoid the researcher's bias in appraising the reflection logs of students. The evaluators, including the researcher, compared the analysis and discussed on some points where they may have had variations. In this case, the evaluation became more objective. The experts were two supervisors in the experiential learning program of the pre-service teachers. The themes generated addressed the problem of this study.

\subsection{Ethical Considerations}

To uphold research ethics, the participants were asked to fill out consent form after orienting them thoroughly on the purpose, process, and benefits of the study. Their anonymity was secured by ensuring that their names were not mentioned anywhere in the paper. In addition, they were advised to withdraw from the study any time they decide to. Moreover, they were advised that they will not receive any compensation as participants of the study, but they were informed of the benefits that can be gained from the study.

\subsection{Enhancement of Quality}

To ensure the quality of the data gathered and trustworthiness, five qualities offered by Lincoln and Guba were observed (Robert Wood Johnson Foundation, 2008). All throughout, the researcher upheld credibility, transferability, dependability, and confirmability that required the avoidance of the researcher's personal bias and those findings were shaped by the participants only.

The themes were generated using varied techniques as the reflections were compared and contrasted. The researcher based his techniques in the study of Ryan and Bernard (2000) that validated ways in generating themes from qualitative data. In their study, they used word repetitions, indigenous categories, key words in context and cutting and sorting. The researcher used highlighters to find similar words repeatedly used by the participants and later grouped them together under the technical lens by Butin. Based on the dominant words used by the participant, themes were formulated.

The inquiry audit was utilized by engaging the assistance of two experts in analyzing the data. Data recording was carefully done to include presenting excerpts of verbatim narratives, while maintaining confidentiality of identity of participants in discussing the data. In instances where the researcher needed to validate entries in the reflection logs, interviews were conducted with the concerned participants.

In addition, to guarantee credibility, transferability, confirmability of data and avoid bias the researcher ensured 
coding of reflection logs. A careful comparison seeking out differences and similarities of responses was employed to arrive at generalizations or conclusions. The study also presented verbatim accounts of the participants to support findings. Casual interviews with some cooperating teachers and supervisors were also conducted to validate the entries of the participants in their reflection logs. The results were also discussed with some cooperating teachers and supervisors. Also, to ensure data sufficiency or saturation, the researcher conferred with two experts for extensive analysis and unbiased analyses.

\section{Findings of the Study}

The preceding section exhorts Butin's a priori on the proposed lens in examining the pre-service teachers' reflection logs as evidence of transformative teaching and emancipation.

Pedagogical schemes of the pre-service teachers comprised Butin's technical lens. This encompasses the pre-service teachers' preferences and options for effective delivery of knowledge, skills and desirable attitude in the context of pre-service teaching, or in their practice teaching experience. The participants were asked to log their insights and experiences as the reflection and expressions of their knowledge, skills and attitude as regards effective teaching in MAPEH. From the analyses, the following themes emerged.

\subsection{Pedagogical Knowledge Schema is a Foundation of Transformational Teaching}

Knowledge schema does not form in an instant. It is refined and widened over time through further exposures. Individuals construct their own understanding and knowledge of the things around them or the world based on their prior experiences and reflections. Encountering something new will require them to reconcile with old views or concepts. This could result to affirming and strengthening prior knowledge or discarding irrelevant ideas (Educational Broadcasting Corporation, 2004). It is imperative that pre-service teachers build on previous experiences as enablers in ushering students towards transformative learning.

It could be gleaned that participants recognized the noteworthiness of acquiring mastery of pedagogical theories and principles before plunging into actual classroom teaching. These are foundational knowledge and skills needed in handling students in the actual field. Teachers need to master the basic knowledge and skills if they desire to achieve high outcomes on the students.

A3 (2015) wrote:

"All throughout my college years, this is the time for me to apply all what I've learned. I need to impart knowledge to my students even if sometimes, as teachers, we have difficulties. I have to unlock it because I should be the subject-matter expert in front of my students. Since learning is a lifetime contract, I have to embrace it by simply reading books for a wider and deeper knowledge."

A3 was convinced that to achieve success in actual field teaching experience, pre-service teachers must possess knowledge or mastery of the MAPEH curriculum. She recognized that pre-service teaching is a period where the accumulated knowledge and skills from classroom training will be used to teach actual students. As Metzler and Woessmann (2012) asserted, teachers' mastery of subject-matter or thorough equipping and preparation is needed to impact positively on student achievement. Extensive preparation empowered the pre-service teachers for transformative teaching.

In addition, another participant acclaimed the importance of equipping himself with the core competencies of MAPEH. This is likewise, an affirmation of the awareness that pre-service teaching experience is the time to apply the theories, principles, and strategies learned from their mentors to equip and empower students as well.

"To become an effective MAPEH teacher to my students, I should acquire more knowledge about our specialization. I should use more references in order to gain more knowledge, read more facts and ideas in order to strengthen my knowledge about MAPEH. And as an effective teacher I should also gain knowledge from my students -it's like a give and take relationship between us. " - B3, 2015

B3 recognized the vital role of classroom learning before dispatching to actual field. Alongside with thorough preparation is the anticipation of unfamiliar classroom scenes which prompted the participant to read books or empirical studies to gain information relevant to the issues encountered. It is also imperative that pre-service teachers take time to reflect on unexpected scenes in class in order to evaluate how the situation was met and if it was handled in a way that students learned from it. This reflection is consistent with the averment of Meyer (2012) that reading is valuable to keep one on top of important things or to get updated with the latest trends relevant to one's field of influence. 
Moreover, C3 (2015) wrote:

"There's a saying that "You cannot teach what you do not know". As an aspiring teacher you yourself must know that you must equipped with enough knowledge before you go to the field. In our case as a MAPEH teacher we have four areas to teach therefore I must master not only Music or Health itself. Each area must be studied and mastered well."

C3 realized that failure to possess pedagogical readiness would cripple teachers in acquiring teaching success. Facing up the rigidities of classroom teaching could be a fierce task. This then requires mentors to be spontaneous and well-harnessed to able to address learning needs and resolve learning issues at hand. Also, this affirmed the conclusion of Darling-Hammond and Bransford (2005) in their study that teaching practice must be based on what is known by the profession as a whole and thus requires professionals to be thoroughly aware of the current knowledge base.

Moreover, the quality of being thoroughly prepared as a teacher was revealed in a longitudinal study conducted by Walker (2008). It was found that preparedness is number one among the twelve teacher characteristics that resulted to positive outcomes to students. Hence, it promoted an implication that emancipation and transformation in teaching and learning are offshoots of a strong foundation which only gets innovated and modified as teachers plunge into actual classroom settings.

The response of the participants of the need to possess pedagogical mastery and continue learning their specialization as they journey to pre-service teaching was encouraging. They were fully aware that interacting with the students would entail realizations and learning moments. Continuous reading would help them cope with unexpected events. This was consistent with the assertion of Muir et al. (2012) that unlike other professions, teachers tend to bring their preparation, firm attitudes and beliefs about what comprises good teaching and good teachers from their own prior experiences as school students.

\subsection{Teachers Must Model MAPEH Core Competencies}

Preparation and readiness, as previously presented, can aid effective pedagogy. However, preparation alone does not guarantee effective teaching delivery. It is likewise imperative that teachers possess the skills inherent with the course. They must walk their talk. They must serve as epitome to the students for teachers, whether they like it or not, are very influential in words and in actions. As popularly acclaimed, "you cannot give what you do not have." Relating that to teaching, one cannot teach what he does not know. This might be deemed too much to be handled by some, but this is aligned with one of the needed characteristics of an effective teacher, that is, to master the subject matter. In fact, Ravitch (2012) highly assuaged that there is nothing more important in the classroom than a teacher who is able to perform the skills of the core disciplines. This claim was supported by Guerriero (2013) who strongly asserted that the decision-making ability of a teacher hinges mostly on his or her knowledge mastery. This leads to another pedagogical option extracted from the participants' reflections. Effective MAPEH teaching requires teachers to possess the talents or skills inherent in the course.

B3 (2015) wrote:

"...for example, on the topic about playing string instruments like guitar, bandurria. Octavina, laud and double bass instead of showing the picture of these musical instruments and telling it that it is played by strumming or plucking. You can play it in front of your students in order to easily adopt it by students. And you can easily attain the objectives of the lesson."

The reflection of B3 implied that skills demonstration is critical in transferring MAPEH skills to students. In Music, students are introduced to various musical instruments and the only way that the teachers would be able to make the students learn is to demonstrate or play with them. Students would learn how to play the musical instruments easier when they actually hold one and start pressing or strumming or striking keys.

Mattesson and Freeman (2006) discussed the vital role of demonstration as a pedagogical option. Demonstration requires teachers to model the skills in order to enable students to take on similar behaviors. MAPEH teaching aims to develop students' musical skills, artistic strokes, sports strategies and health management skills which could be best transferred through demonstration teaching. In addition, the Learning Pyramid (2016) illustrates that active participation in the learning process results in higher retention of lessons. Practice by doing registers (75\%) has greater effectiveness compared to lecture (5\%) and audiovisual (20\%) learning.

In addition, B1 (2015) wrote:

"I know how to play Rondalla Family Instruments like Banduria, Octavina, Laud, Double Bass and Guitar. I'm a Percussion major, I know a little bit of piano and Angklung. I know how to officiate different kinds of 
sports and also I know how to play them, Board games, I also know how to swim. I know how to execute First Aid. I have enough knowledge about all the components of MAPEH. Like in Music, we learned all the different genres in different Musical Eras in Western Country; the different musical characteristics here in the Philippines, Asia, and Western countries. In Physical Education, we were taught about all the sports whether it be dual and team sport, also the gymnastics in Health, all of its components, the First Aid, Anatomy and alike. In Arts, we were taught about all the painting techniques, and art related subject."

B1 claimed that he had acquired sufficient knowledge in MAPEH from knowing the different genres in various musical eras and countries. He also claimed to know about the types of sports and health components. As previously discussed, MAPEH comprises four components or disciplines with differing knowledge and skills. Teachers must be adept in all four component competencies for effective transfer to students. They should be able to model the skills they expect their students to acquire. Such is what the University of Washington (2016) highly recommended in achieving teaching excellence. Teacher-leadership is no longer optional. It is needed for meaningful learning to take place. Teaching leadership requires teachers to demonstrate, coach, and guide students toward the achievement of learning goals.

Moreover, A1 (2015) opined:

"As a MAPEH teacher (student teacher), I should have athletic skills for me to be an excellent role model to my students. I must have a good health for me to teach different Physical Education activities. I must also have motivational skills because I have to teach my students how to value a good sportsmanship like behavior and teamwork and specially, I must also have teaching skills for me to be able to have confidence to face my students no matter what."

In a similar fashion, A1 put forward the view that modeling skills is sine qua non in teaching. To teach MAPEH confidently, A1 contemplated that teachers must possess the skills required. This was corroborated by Shulman (2015), from the National Board for Professional Teaching Standards, when he deemed that to teach effectively, teachers must know five teaching propositions. Out of the five propositions, Proposition 2, which stated that "teachers must know the subjects they teach and how to teach those subjects to students," closely supported the reflection of $\mathrm{A} 1$ on the need for teachers to possess the competencies that would positively influence others. This insinuates that MAPEH teachers must be proficient with the knowledge and skills and must be able to demonstrate these competencies to students. Shulman (2015) further espoused that “...teachers must model all behaviors, help students advocate for themselves in the classroom and in the community..." MAPEH teachers must model knowledge, skills, and values that would translate and transcend to students to achieve effective teaching and learning.

Furthermore, Lopez (2015) asserted that successful teachers share the idea of positive thoughts and positive demeanor when working with students. If they desire optimism among students, they must be optimistic themselves. This was corroborated in the study of Barros and Elia (1997) about the effect of attitude of teachers to their students. The study found that a teacher who believed she was highly able to conduct interactive class in Science and actually exuded dynamism was rated outstanding by students. This implied that teachers' attitude and her ability to model the skills in class contribute to positive student outcomes.

Even so, C2 (2015) wrote:

"I should have enough knowledge that I need to be able to teach MAPEH effectively; I should have equipped myself for the knowledge that I need. For example, I am going to teach how to play Arnis, then I should know the history of it and how to play it."

The reflection of $\mathrm{C} 2$ was similar with the other reflections presented previously. To teach arnis, $\mathrm{C} 2$ presumed that he had to be acquainted with it. He had to know the mechanics of the sport. Teachers cannot teach what they do not have. This applies to all the competencies in MAPEH. Since MAPEH is composed of varied disciplines, teaching the subject auspiciously would require teachers to possess multiple competencies.

The reflection logs showed the realization of the participants to be musically inclined, physically fit, artistic and versatile. For example, they had to play at least one musical instrument, be physically fit/athletic, and creative. This affirmed Garcia's (2010) claim that, “A P.E. teacher must be educated and knowledgeable in a variety of sports such as tennis, basketball, football, baseball, softball, rock climbing, aerobics, gymnastics and a host of other disciplines. The quality of recognizing what sports require teamwork and what sports are individually played is a Physical Education teacher's responsibility. Physical Education teachers themselves must be physically fit."

The participants were aware that to be empowered classroom teachers, they had to walk the talk or model the required competencies. This was affirmed in the findings of Daluba (2013) that demonstration as a teaching strategy resulted to the significant performance of students compared to the conventional method. 
It is important that MAPEH teachers put premium to learning and training themselves with musical skills, artistic strokes, and knack of sports. They must be able to demonstrate or model these skills as stressed by the National Center for Education Statistics (NCES, 1999). It is important that teachers continue learning and mastering the skills. This is especially true in a profession where the demands are changing and expanding such as in education. Teachers do not stop learning - they continuously update their knowledge and upgrade their skills by attending seminars, workshops trainings and short-term courses (Desimone et al, 2002; Salas, 2018), enrolling in graduate degrees (Punzalan, 2019; Masangkay, 2018; Salas, 2018), and engaging in other professional development activities (Desimone et al, 2002).

\subsection{Values and Positive Attitude are Requisites of Transformational Teaching}

Preparation and modeling are expedients to meaningful learning. In connection, transformational teaching goes beyond ensuring that teachers possess the exigent competence which effectively translates to students. It steps to a higher mission - that of transforming lives and touching hearts. While the demands of teaching could be stressful, teachers must show altruism. Teachers must radiate warmth and positive attitude that would incite learners to get involved. Transformational teachers possess genuine intention to influence students toward improving themselves (Slavich \& Zimbardo, 2012).

Results from the reflective logs showed the top teacher qualities for effective teaching and these included having positive attitude, being patient, being open-minded, being approachable, being firm and being role models. The reflections attested the pre-service teachers' perception that values and positive attitude were necessary to fuel student engagement. Positive attitude would spur learners' interest and in effect will lead to greater input in their knowledge bank.

As the reflection of A1 (2015) goes:

"I must possess good attitude towards my students in order to build up a harmonious relationship (towards my students) between me and my students. Because if I don't have good attitude they will never listen to me and they will remember me as a terrible teacher."

A1 valued building up a harmonious relationship with the students. To achieve this, A1 should possess positive attitude. If he wanted the students to display right attitude, he had to exemplify that attitude; otherwise, students would not listen to him. Undoubtedly, possession of positive attitude would have a metastatic effect to students' motivation to learn and engage in class. Positive attitude would result to a learning environment where students are free to interact and participate in the discussions. This was consistent with the findings of Ulug, Osden and Eryilmaz (2011) in their study which revealed that teachers' positive attitudes had positive influence to students' personality and their life performance.

Another participant (A2, 2015) wrote: "I should be patient, understanding, open minded and I should have a big heart so that I can teach MAPEH effectively." The participant recognized the need to be patient with students. Being patient means to have a big heart or love and care towards the students. It is needed in today's classroom environment with students having varied needs and learning styles. This is why Anwar (2011) averred that patience is the most important character of a teacher. It is one of the most powerful weapons in winning students' attention and focus.

This was experienced by Wormeli (2016), a seasoned teacher. He stated that patience in teaching entails dedicating considerable time in building prior knowledge of students, especially to those with little exposure and retention. It also requires teachers to assess the readiness of students of new learning and their learning acquisition. Teachers need to bring in patience to the learning equation, not just content. They have to possess the fortitude as they expect to extend tenacity and hope to students. As stated by Wormeli (2016), the sooner that a teacher had a full grasp of patience as a non-negotiable element in teaching, only then can they fulfill their mission. Effective teaching and learning thus takes time and robust expertise.

Moreover, some reflections touched on the importance of punctuality, passion and respect in teaching. A participant (B5, 2015) wrote: "I must be on time, passionate and be dedicated to my work." Passionate teaching, which was expressed by B5, is manifested by the teachers' high degree of commitment and loyalty to students' learning acquisition. This is possessing fervor and devotion to teaching and concern for student development. As such, Smoot (2013) characterized great teachers as those who have humility in knowing that they serve a purpose larger than themselves. He observed that the best teachers inspire students to make their own way forward. They are the ones whose passion is not only seen in their outward behavior but in their deep desire to know more about the content they taught.

The impact of passion and dedication to work was studied by Mart (2013). He claimed that teachers are distinguished by their commitment to achievement of their students. He concluded that passionate teachers are those who make 
great changes in students' lives and there was a strong correlation between passionate teaching and successful student learning. Hence, commitment, a sense of adherence, is a key factor that influences learning process of students. The reflection of B5 was affirmed in the study conducted and accounted.

Another pre-service teacher indicated:

"Even though you master all the subject area of MAPEH or other subjects and even if you are very intelligent but if you do not have the proper attitude towards teaching you want to be that effective. You must be a good model to your students, show them that you love what you are doing." - C3, 2015

Proper attitude, which C3 expressed, is always looking at the bright side. It is described as using constructive thinking, having an attitude of happiness and having the motivation and energy to accomplish things. C3 perceived that positive attitude is shown in loving the work of teaching and having this is more superior to intelligence when it comes to achieving success in teaching.

Valuing positivism in teaching is consistent to the conclusion of Fehintola (2014) in a study about factors that affect student performance. Together with teacher qualification, knowledge and job satisfaction, work values of the teachers and attitude were potential factors in the academic performance of students (Nool, Ladia \& Balanquit, 2018; Nool, 2014).

All the participants' reflections captured what Sheehy (2012) underscored on the importance of being a role model when teaching Physical Education. Teachers must be optimistic, positive, and fair in class when they want their students to learn the importance of fair play during games. They have to be humble and considerate when they want their students to learn humility in winning games and to be considerate about the feelings of the losing team in a game.

Teaching may not make anyone's wallet full and may not make anyone wealthy with all the riches in the world, but what makes some people driven into this profession could be traced within the roots of passion and commitment; they are two of the most important elements which fuel the tank of every teacher to feed the hungry souls and minds of multicultural and diverse students. Passion and commitment to teaching are paramount in transformational teaching. Teachers need to continue with heightened determination to make a difference in the students' lives. They need to possess values that will inspire students to attain excellence in knowledge, skills, and interventions. These are the necessary tools in transformational teaching.

\subsection{Communicating Expectations Lead to Responsible Learning}

Teachers set the tone of the learning environment. They are responsible for creating a warm learning environment that allows students to interact freely and grow. They must instill openness between and among the students. They must make students responsible and accountable for their learning. Teachers must communicate their expectations to students before they can take responsibility for their own learning. Solomon (2015) refers to setting expectations as Pygmalion effect or a self-fulfilling prophecy. Expectations improve student behavior and performance. The reflections of the participants reverberated communicating student expectations as significant in achieving responsible and meaningful learning. It is apparent from the reflections that participants recognized their preponderance of imparting expectations to students. A7 believed that students would be motivated to reach their goals if they were assisted and guided by their teachers to display expected behavior or performance in class.

"As a future teacher, I'll help students see learning tasks as meaningful. I should develop a bond with my students and cease seeing my students "as the other" and I'll find ways to communicate high expectations for the success of the students and the belief that all students can reach their goal." (A7, 2015)

A7 believed in the potential of setting high expectations in motivating students to achieve success. Students must understand what they are expected to learn before they can take responsibility for their own learning. When teachers set high expectations for students and communicate these clearly to them, their tendency is to work hard to meet the challenge (UNC Charlotte, 2008). This is consistent with the findings of Tsiplakides and Keramida (2010) in their study on the effect of communicating expectations to students in an English class. They found that a positive relationship exists between setting expectations to students and their achievement in English as a foreign language. The study concluded that the self-fulfilling prophecy effects of teachers' expectations constitute an important affective variable in learning.

In addition, C2 (2015) also believed that communicating student expectations would make learners responsible.

"Yes, positive expectations for all students is very important. No matter the skill level or natural ability of the students, all students have the ability and desire to succeed. Despite different expectations for different students, all students are entitled to your help, attention and feedback." 
Communicating positive expectations or talking directly to students would send a message of respect and confidence that they have the capacity to accomplish learning tasks. C2 believed that all students, no matter how different they are from one another, need attention and feedback. If they feel important and assured that they are important, it is easy to catch their participation in class. This was affirmed by Goodrich (2012) in his pronouncement that students tend to support each other in learning tasks and become responsible by evaluating actions with expectations. Similarly, Zimmerman et al. (2014) noted that rapport with instructors and communication of expectations increased their motivation to participate in class activities. These studies affirmed the reflections of participant that communicating expectations would germinate positive learning outcomes.

\subsection{Engaging Students in Pedagogical Activities for Transformative Learning}

Traditional teaching is subject-matter centered. The teacher is the most important actors of the learning environment since they are the sources of knowledge relayed to students. However, modernization necessitated a shift in teaching paradigm such that educators regarded students as the center in the learning process. It is also possible if students find learning activities meaningful (James, 2015). The reflection logs of some participants showed their grip on active student engagement for transformative learning. Based on the reflections of A7, learning activities are effective reinforcements. Teachers must stimulate students to explore in their environment and take part in group activities. Students must not only listen and memorize; instead, they must demonstrate a process, analyze an argument, or apply a concept to the real world. In the process, they develop deep understanding of a concept and use this understanding to cope with their difficulties. As what A7 expressed:

"First, let them explore to develop their skills. Second, make an activity that they can identify what talent/skills they have and lastly, engaging them to sports or dance that they're interested." (A7, 2015)

The University of Washington (2016) reported the findings of a research that engaging students in the learning process increases their attention and focus, motivates them to practice higher level critical thinking skills, and promotes meaningful learning experience. In this study, participant A7 ensured the provision of activities to enable meaningful learning. Student engagement in class activities stimulates internalization of lessons and eventually results to meaningful learning. This was consistent with the findings of White and Nitkin (2014) in their study that student engagement in learning demonstrated deep and positive impact to personal growth, academic habits and attitudes, student leadership and initiative and a sense of community in the school.

Analogously, C1 (2015) indicated: “... By letting them to go outside and having an activity outside the class to change the environment of their learning." According to $\mathrm{C} 1$, carrying out activities outside class allowed students to enjoy their lessons. A change in the learning environment enervates boredom. It makes learning fun and enjoyable. Chavez (2016) substantiated this when he discussed the benefits of field trip as a method in teaching. He said that field trip is an effective educational activity for students as it helps facilitate fast and efficient learning. It is a wonderful opportunity for students to take a break from a classroom lecture and have some fun and excitement in an entirely new environment. This is congruous to the study conducted by Guo (2011) which determined the impact of out-of-class activity on students' English awareness, vocabulary and autonomy. Results showed that out-of-class activity has expanded students' awareness of the English language available to them outside their classroom and had added to the degree of students' autonomy in learning.

In the same way, MAPEH classes would be better appreciated if students are brought outside the four corners of the classroom. Students can draw inspiration from the environment in developing art work. They will also perform physical activities better in the ground rather than in the classroom. In Music, they can be brought to singing groups or musical ensembles where they can better appreciate musical renditions.

Malone (2014) underscored the benefit of learning outside the classroom based on research reports. Children and young people reportedly experienced a change in the way they engage and learn through the natural, cultural and physical world. Due to fear, parents and teachers withdraw their children from public places, such as parks, streets and community facilities, which in turn limit the learning of the children. One of the salient findings of the study was the revelation that physical activities in school grounds provided significant impact on the learners. In addition, sociability, through verbal interactions, is a key benefit of school ground play. More so, emotional, psychological and spiritual benefits were evident when learners play in school ground.

On the outset, Finley (2014) contended that transformational teachers create constructive experiences where students are actively engaged in learning while the teacher facilitates developing knowledge and skills; develop critical thinking; higher-order skills; and communication. The participant' reflections showed that they recognized the importance of class participation in bringing students to the core of learning. 


\subsection{Motivation Fuels Student Meaningful Participation}

Engaging students in the learning process is not instinctive. Teachers need to devise strategies to motivate them to involve in classroom learning activities. Motivation directs behavior toward particular goals and increases initiation and persistence in activities; it can lead students on the road to successful classroom learning and productive behavior (Ormrod, 2014). Motivation has something to do with the students' desire to participate in the learning process.

In this study, the reflections of the participants showed their knowledge about the vital role of motivation in the classroom performance of students. According to B3 (2015): "The teaching and learning process will be more interesting to the students, they will be more motivated; I can use to get and keep the attention of the students and it can encourage the learners to learn." B3 accentuated motivation as a key in catching student's attention and in encouraging them to participate in learning activities. Arousing students' interest is a strong catalyst that would propel students to take on tasks that they genuinely want to complete and would enable them to expend significant effort to complete tasks to the best of their ability. B3 implied that motivation is immensely significant in triggering the desire and enthusiasm of students. It drives students to accomplish their goals, maintain their responsibilities or solve their problems.

Christie, Carey, Robertson and Grainger (2008) affirmed this when they stressed that students who are given the proper motivation, the means and the knowledge to critically assess, challenge and change their assumptions, would have the chance to become life-long learners who are capable of acting for the best in a rapidly changing world.

Similarly, B4 (2015) wrote: "I can make the class alive a set or addition of the motivation in the class, and make the lesson easy to understand and my teaching more effective." Making the class alive may mean setting a learning environment free from tension or pressure. In so doing, the students are free to voice out their ideas or to participate in class. B4 is apparently convinced that fostering vibrant class will result to better comprehension of lessons. This was shown in the studies conducted by Abdullah and Akhter (2015) and Amanah (2019) which revealed that humor in an English class enhances students' learning ability. It reduces the anxiety factor and boredom in class. It creates an English learning environment that inspires students to perform better.

Harrison (2011) underscored the role of motivation in achieving transformational leadership. Teachers who exemplify transactional leadership inspire everyone to engage and ensure that leaders and followers raise one another to a higher level of motivation, performance and morality.

\subsection{Collaboration and Cooperation Facilitate Learning}

Notwithstanding the potential role of motivation in arousing attention and engagement of the students, learning together in groups is also potential in effective pedagogy. Successful teaching is easier achieved if teachers facilitate the creation of independent, self-directed, and self-motivated learners who are capable of critiquing and directing their own work, who are open to alternative viewpoints, and who have strongly developed higher-order thinking skills (Mintz, 2015). An example of this is using cooperative learning as an approach in teaching. In cooperative learning, the teacher forms small groups or teams and they are given tasks to do in relation to the lessons they have on hand (McIntyre, 2014). Students are allowed to discuss together and accomplish tasks, answer problems or questions. The reflections showed that participants had employed cooperative learning to allow them to share and learn together in the group.

According to B6 (2015): "I had applied cooperative learning in my teaching because I believed the learners are being grouped and they will be the one to share it to their group." B6 applied cooperative learning to encourage sharing in small groups. Students who were shy to interact in class got the chance to be actively involved in a smaller number of groups. It also stimulates critical thinking and helps students clarify ideas through group discussions and debates. This reflection was supported in the study of Pal et al. (2012) which assessed the impact of small group teaching in fostering intricacy of interaction so that learning could be facilitated. Findings revealed significant positive results of forming small group in promoting intricacy of interaction and positive learning.

In addition, C6 (2015) wrote: "I do cooperative learning because cooperative learning is good, two is better than one. I obtain the objectives of my lesson..." Participant C6 believed that cooperative learning facilitated the acquisition of the learning objectives. Students feel more responsible and accountable for their group performance and do their best to fulfill their tasks. In this manner, they work hard to unite and resolve conflicts which may distract their focus in accomplishing tasks.

More so, forming groups create a feeling of confidence among the teams and encourage creativity. Each team may attempt to be unique from the rest of the groups so they try to deviate from the usual processes and old ways. In line with this, C3 (2015) also shared his experience in class:

"Yes once we had a debate about what age should a girl and a boy should start dating. I group them into two 
and give them time to discuss their topics then after that they started debating, proving their answers and reasoning out. They were all engaged in answering each question. And they all have an idea that they wanted to share. They are enjoying while they are learning."

To teach a lesson in an interesting manner, $\mathrm{C} 3$ chose to present it in a form of debate. This entailed forming groups and providing time to allow members to discuss and reason out together and $\mathrm{C} 3$ observed that students enjoyed a lot. The activity had stirred students' hyped up emotions and desire to win over their opponents. This activity agitated students' capacities and talents and inspired them to contribute their best to win.

According to the Academy of Diversity and Inclusive Education (2012), transformative learning gives learners the ability to think autonomously. It allows learners to develop their own sense of meaning. Autonomous thinking is vital for full participation in a free society. Cooperative learning allows independent learning of students as they are allowed to learn independently from the teacher.

Slavich and Zimbardo (2012) contended that instructors should be intellectual coaches who create teams of students who collaborate with one another and with their teacher to master bodies of information. They accomplish these goals by establishing a shared vision for a course, providing modeling and mastery experiences, challenging and encouraging students, personalizing attention and feedback, creating experiential lessons that transcend the boundaries of the classroom, and promoting ample opportunities for reflection.

\subsection{Engagement of Learners Requires Humor and Energizers}

Motivation and active learners' engagement in groups must be sustained by the teachers. They must strive to succor learner-centered teaching which has been encouraged in schools as opposed to subject-matter centered teaching (Blumberg, 2015). This teaching approach empowers the learner to take an active role in the teaching-learning process. It takes into consideration the assessment of readiness of the learners and their prior knowledge. Teachers have to ensure they are properly motivated and ushered into the learning activities. They have to be observant of students who lose interest in class and must be able to bring them back in track.

The participants recounted cracking jokes at the middle of the discussions to break the monotony inside the class, especially to students who easily get tired or bored of listening to the teacher's discussions. Corollary to this, promoting light discussion through the use of jokes is deemed vital in retaining the attention of the students within the class; failure to capture the attention of all the students within the class would also lead to failure to impose new learning to these young minds.

As A2 (2015) shared: "I asked them why he or she is sleepy and not listening and after that I'm going to give them some jokes or activity that will wake up their sleepy heads." A classroom scenario in which students feel sleepy is common, especially during the holy hours. This echoed the experience of A2. She spotted a drowsy student and instead of apprehending the student, A2 cracked a joke. This is a positive way of getting the attention of the student, rather than scolding or embarrassing him/her in front of the class. The reflection of the pre-service teacher was in harmony with the findings of Shiyab (2010) that majority of the students believed humor can both increase their understanding and knowledge of their subject and can motivate them to learn. In addition, Elias (2015) espoused that humor reduces tension and stress in class and in turn causes students to achieve creative understanding. McNeely (2015) also reported of a research finding which revealed that brain scans registered high levels of activity in multiple areas of the brain when humor was used in conversation and instruction.

Similarly, B7 (2015) indicated: "My strategy is making the class a fun place because I need to deliver my lesson to my students with a smile and remember all the things that I say even the jokes part is so effective because as they remember the joke some important information or word that they must use in answering my question." The participant observed that students acquired better retention when lessons were delivered using humor, which Black (2006) described as a peculiar human trait found within the realm of communication process. Students were stimulated to answer questions which cause them to gain better retention. This was consistent with the analysis of Weimer (2008) which revealed that humor in educational settings serves a variety of positive functions beyond just making students laugh. Humor builds group cohesion and inspires learners to respond positively.

A6 (2015) also wrote: "First you should start on a good motivation and interesting one, second must have a sense of humor and lastly use your voice properly, don't be a monotone discussant." A6 believed in setting a positive learning environment before starting lesson presentations. The strategy implemented was to give motivation, humor, and avoiding monotonous voice to avoid boredom. A professor's humor can create an enjoyable milieu which is conducive to learning and which is welcoming for student participation (Neulip, 1991; Korobkin, 1988). Thus, creating a positive learning environment would allow students to feel comfortable, safe and engaged. Using 
strategies that would create a positive learning environment in transformational teaching was underscored by Miller (2016). His long years of teaching led him to conclude that no matter how talented, no man is born to be a teacher. One has to take significant care and effort to hone his craft to be committed to continued professional development and refresh his status as a transformational teacher and constantly share his best practices. More importantly, he stressed that teachers could observe the best practices of other teachers. He experienced this when he observed that students in an English class of his colleague were more relaxed and engaged because he injected humor in discussing their topics. After his observation, he also tried to use humor in his History class.

\section{Discussion}

This study described and investigated transformative teaching and emancipation pieces of evidence of MAPEH pre-service teachers' reflection logs using Butin's framework as a guide. Pre-service teachers found their exposure to the actual field as an avenue for transformative teaching and learning. They appreciated the knowledge and skills which they acquired from their instructors prior to their field experience. Eliciting and building on prior knowledge is a central tenet of a learning theory associated with teaching for understanding. The more experiences the pre-service teachers have, the more opportunities they have to store academic background knowledge. Likewise, pre-service teachers were convinced that talents and abilities inherent to their specialization such as being musically inclined, athletic and artistic are necessary for successful teaching.

Content, pedagogy and talents are necessary tools in transformative learning. These are to be strengthened by daily observations and reflections of the behavior and responses of students - what made them more engaged and what caused them to feel bored. Pre-service teachers also realized the need to possess the virtues in teaching of liability, open-mindedness, compassion, obedience, patience, authority, role modeling, exuberance, novelty, trustworthiness, intelligence, strategic competence, and skillfulness which catapult them toward transformative learning.

Most importantly, pre-service teachers were challenged to examine their teaching approaches in an attempt to shift their attention from an achievement approach with the outcome-based approach. They were observant and reflective. They observed the behavior of the students - what captured their interests, what made them appreciate their lessons, and what made them understand the lessons clearly. They were able to reconstruct prior knowledge to respond to the new learning environment.

In addition, they looked into the diverse needs of the students and tried to address them effectively. They exerted effort in learning about their cultural uniqueness and needs. Moreover, the participant' reflections showed pieces of evidence of the realizations which included acknowledgment of the need to read and study more to cope with daily classroom encounters. They reckoned the importance of recognizing learners' varied learning styles and preferences. They responded by making efforts to suit teaching strategies and learning activities.

Moreover, some participants thought that they should have prepared more before they plunged into the world of pre-service teaching. This enabled them to make sense of themselves and the world. They realized that their prior knowledge is not enough to address the learning needs of the students. They were able to cope by reading more, continuing to study, and seeking inputs from their cooperating teachers.

Pre-service teaching, indeed, is a promising avenue for transformative learning through reflective thinking and meaningful observation of the behavior of students, their learning preferences and connection to their personal lives. It is the peak of the student teachers' exposure before they soon join the pool of professional teachers. They have the opportunity to influence students to make sense of themselves and realize their role and significance in improving the community where they belong.

Pre-service teachers must construct knowledge, continue to extensively read related materials and exercise flexibility, creativity and innovation to achieve transformational teaching and learning. This affirmed the National Center for Education Statistics' (1999) claim that teachers must continue to learn in order to cope with the demands of a constantly changing society.

Accordingly, classroom learning may help equip the pre-service teachers with the fundamental principles of teaching but they may not be fully equipped with the teaching tools appropriate in a particular learning environment. In reading, teachers must exhaust wide array of references to enrich classroom learning.

In addition, pre-service teachers must ensure that they have imbibed the core concepts inherent to the discipline components of MAPEH. In autonomous teaching or transformative learning, pedagogical strategies may vary from one learning environment to another - prompting pre-service teachers to exercise good decision-making, but the core concepts remain. Consequently, pre-service teachers must possess mastery of the fundamental skills of the disciplines. They must know the specifics or details of MAPEH. 
Moreover, pre-service teachers valued listening to the views of students. This is possible in sharing and collaboration in a group (cooperative learning) - they believed that exchanging ideas in small groups will allow critical learning to flow. Lugo (2009) draws significant benefit of collaborative learning in achieving transformative learning. In collaborative learning, students are responsible for their own learning. They develop a sense of independence with guidance and scaffolding from their teachers.

Transformative teaching could also work well through modeling the skills and exuding positive attitude. Emancipation in teaching could be achieved if pre-service teachers are optimistic that they can transform an environment by being innovative. They must also possess necessary virtues and humor that propel them towards positivity and eventually, transformation.

Creativity was also deemed important in teaching given diverse learners and a changing environment. A participant, in fact, mentioned about the need to innovate teaching strategies considering the $\mathrm{K}$ to 12 directives in the implementation of the $21^{\text {st }}$ century teaching skills.

Furthermore, the participants showed in their reflections the need to develop communication skills to achieve effective teaching. They had to clearly convey the concepts to the students to ensure success in knowledge transfer. They also recognized that they must apply the good qualities or values in teaching to be able to invigorate learning. If they were fair, open, honest, respectful, considerate and kind in class, they would expect a free flow of interaction.

The participants also appreciated the value of asking questions to students to find out if they had acquired learning. In return, they also encouraged students to ask them questions to verify or clarify their doubts. The participants, in fact, were motivated to join discussions or give their opinions in class discussions. Lastly, participants made an effort to break the monotony by carrying out activities such as putting the class in games, listening to music and putting up debates. They had to be creative in order to keep the class interested.

These principles are relevant in achieving transformative learning and emancipation. Teaching should not be confined in a box. According to Lam (2016), teachers must be flexible and grow with the flow in a learning environment. They must embrace change and must deviate from the plan if situation warrants it so. Effective teachers reflect on their teaching to evolve as successful teachers. In addition, teachers must hinge on the multiple intelligence theory - that not all learners are alike. The American Institute for Learning and Human Development (2015) stressed the importance of applying multiple intelligence theory among teachers who experience difficulty in reaching out to learners outside the normal curve. The theory enables them to design teaching plans appropriate to learners considering their inclinations.

Further, they realized that actual field of exposure enriched their teaching skills. They acknowledged the need to continue on learning in order to enrich their prior knowledge. The participant claimed they continued to read books in order to cope with teaching difficulties. Lastly, the participant realized that versatility helps in attaining effective teaching. They came to a realization that they must not stick to single or few strategies in teaching MAPEH.

With regard to the experiences of the participants that led them to design strategies, most of them claimed to have suited their strategies to the students' learning styles and interests. They also considered the cooperating teachers' inputs in choosing appropriate strategies.

These participants were able to use effective strategies that they have reflected on while teaching. They discovered that victorious MAPEH teaching entails the use of varied teaching strategies to include cooperative learning, valuing learners' characteristics and interests, and carrying out variety of learning activities. Since MAPEH comprised several disciplines, teachers must employ wide array of strategies. Mintz (2015) asserted that successful teaching involves much more than delivering the content and skills. The goal of teaching is to create independent, self-directed and self-motivated learners who are capable of metacognition, directing their own work and have developed higher order thinking skills. Cooperative learning is needed to achieve these among the learners. However, it could be seen that pre-service teachers missed out on inquiry-based teaching and problem-based learning approaches that could have contributed substantially to transformative learning and emancipation.

Finally, the reflection logs of the participants provided evidence of transformative learning and emancipation which included their belief that they can do something in the lives of the learners, they developed sense of responsibility and accountability, they felt accomplished and happy, they believed that they possess the necessary knowledge and skills to influence students; and they recognized the need for continual transformation towards the achievement of satisfaction. These were borne out of the pre-service reflections on their teaching, self-evaluation and their resolve that they can do something to make things better in the classroom. These supported Cooper's (2014) contention that experience, critical reflection and rational discourse characterize transformative learning. 


\subsection{Implications to Teacher Training}

Pre-service training is aimed at enhancing the experience of pre-service teachers to fully prepare them for professional teaching once they graduate and apply for teaching jobs. This is a chance for them to apply the theories in an actual learning environment. This experience could be challenging but is considered vital in training the pre-service teachers towards achieving teaching excellence. The reflections of the participant showed that generally, they had meaningful teaching and learning experience. They had the opportunity to share their knowledge and skills. Some were very happy to have touched the lives of their students. Undeniably, some had incurred frustrations with their superiors which cannot be totally eliminated in the actual field. However, the mentors must be constantly reminded that they have, within their hands, budding teachers so they must act appropriately. They have to model the ideals of good leadership and pedagogy.

Moreover, practice teaching supervisors should check the reflections of pre-service teachers from time to time. These reflections should not serve as a means of summative evaluation but a means of extending assistance; especially, since some may not be able to verbalize their classroom challenges to their supervisors. Their reflections, ergo, would reflect their needs.

Furthermore, the participants of this study recognize the importance of having thorough and comprehensive content and pedagocial mastery in effective teaching. The decision-making ability of a teacher hinges mostly on his or her knowledge mastery (Guerriero, 2013). As Ravitch (2012) aptly put "There is nothing more important ... than a teacher who is an expert in his/her respective field." This principle has significant implications to pre-service teacher education. Teacher education institutions should ensure that pre-service teachers possess and demonstrate mastery of meaningful and comprehensive knowledge of the subject matter they will teach as well as deep and principled understanding of the learning processes and the role of the teacher in facilitating these processes in their students (CMO No. 30, s. 2004).

Before any person is allowed to practice as a professional teacher in public and private elementary and secondary schools in the Philippines, the government requires them to have a valid certificate of registration and a valid professional license from the Professional Regulations Commission (Republic Act 7836). To acquire a license to teach, teacher education graduates must pass the licensure examination for teachers (LET), which assesses their mastery of general education, professional education and field of specialization. Unfortunately, TEI graduates registered low passing rates in the LET from 2009 to 2017 (Cepeda, 2017; Dagdag et al., 2017; Ladia, 2014; Ladia \& Nool, 2011, 2012, 2017; Mateo, 2017; Nool \& Ladia, 2017; Nool, 2018).

Various factors affecting licensure examination performance have to be considered such as college admission test (Balagtas \& Gerundio, 2014; Bansiong, 2019; Cahapay, 2020; Callena et al., 2019; Dagdag et al., 2017; Nool et al., 2017; Pascua \& Navalta, 2011; Ruben, 2014; Solis-Foronda, 2017), general scholastic aptitude (Bansiong, 2019), college grade point average (Amanonce \& Maramag, 2020; Bansiong, 2019; Cahapay, 2020; Chan-Rabanal, 2016; Dagdag et al., 2017; Esmeralda \& Perez-Espinosa, 2015; Ferrer et al., 2015; Kalaw, 2017; Pascua \& Navalta, 2011; Solis-Foronda, 2017), mock board examination and competency summative test (Bansiong, 2019), teaching aptitude test (Visco, 2015), retention examination (Balanquit et al., 2018; Corpuz, et al, 2017), English proficiency (Kalaw, 2017; Pascua \& Navalta, 2011), educational attainment, teaching experience and competence of faculty members (Nool, Balanquit \& Ladia, 2018; Quiambao, 2015; Ruben, 2014), LET review classes (Albite, 2019; Aquino \& Balilla, 2015; Ferrer et al., 2015; Mendoza, 2014; Tan, 2016; Visco, 2015), accreditation status (Galenzoga, 2016; Gutierrez, 2016; Nool et al., 2018; Rosales et al., 2014), and library facilities (Quiambao et al., 2015).

Considering the mentioned factors and CMO No. 75, s. 2017, the College of Teacher Education has been implementing admission and retention policies and continuously improving its facilities and practices in order to prepare teacher education graduates who can successfully pass the licensure examination and can effectively teach in the classroom. In addition, appropriate measures have been implemented in the College such as developing instructional materials (Corpuz, 2017; Mendoza, 2015; Morales, 2015; Nool, 2009; Nool, 2018; Samson, 2016), assessing students' competencies (Embesan, 2014; Nool, 2011) and conducting different intervention activities (Balanquit et al., 2018; Corpuz, 2015; Embesan, 2004; Ladia, 2015; Masangkay, 2012; Mercado, 2018; Quiambao \& Punzalan, 2019) to enhance teacher education students' academic performance.

\subsection{Conclusion}

The participants recognized the importance of building on prior knowledge for effective transformational teaching and establishing a learning environment which encourages learners to engage in active construction of knowledge is based on prior knowledge. Most pre-service teachers believed the theories and principles they learned from 
classrooms are the precursors for transformative teaching. In addition, they perceived that transformational learning occurs if students see them walk their talk. Students must see them empowered, dynamic and self-motivated before they can become like them. Further, immersing students in classroom activities would help them explore and grow. Putting students in the heart of teaching would encourage them to use their potentials in accomplishing daily requirements. Immersing students in pedagogical activities enables transformative learning. The more students are actively engaged and motivated in learning activities, the more positive the outcomes in learning become.

Similarly, teachers may produce positive outcomes if they communicate their expectations to the students. Letting students know what they need to accomplish, will motivate them to work hard. Expression of conjectures fosters meaningful learning. Therefore, if teachers clearly communicate their positive and high expectations, students would most likely level up to the challenge and be more responsible learners. In fact, pre-service teachers were also convinced that espousing values and embracing positive persona are requisites for integral teaching. Teachers' positive attitude in dealing with the learners could encourage open and warm engagement since the learning environment is free from tension. Too, transformative teachers appeal to affective domain. They would neutralize tensions and boredoms through humor to create an environment where students are free to learn and explore. Humor is a powerful force that can encourage openness, develops students' divergent thinking and enables a relaxed learning environment. Teachers must also continue to motivate and allow dynamism in class by putting learners in small groups where they could discuss, reason out, or brainstorm to achieve meaningful learning.

\subsection{Limitations and Directions for Future Research}

The researcher acknowledged some limitations of the study. Firstly, the researcher failed to observe all the participants in their classrooms to record his own observations. His observations were only confined to three participants whom he handled in the pre-service teaching. Secondly, no information was generated from the cooperating teachers; parents and students were not also interviewed. Thirdly, the researcher mainly based his analyses on the data from the reflection logs of the pre-service teachers.

In view of these limitations, future studies may be conducted to enable more comprehensive gathering of data from all the stakeholders so that the reflections of the pre-service teachers may be validated and to to come up with a more credible and conclusive generalizations. This will enable deeper understanding and appreciation of the ability of the pre-service teachers for transformational teaching. The deeper is the understanding of the teachers' ability for transformative teaching, the better curriculum will be designed for pre-service teaching that will allow pre-service teachers to be more reflexive of the events in their learning environment.

In addition, researchers may also conduct future studies that will look into the impact of teachers' ability to use their reflections in designing teaching plan to learners' outcomes. After all, the noble goal of teaching is to transfer knowledge and skills to the learners to empower them to transcend beyond classroom learning.

\section{References}

Abdullah, R., Ghufron, M. A., Puspitasari, Y., \& Ahmad, N. (2020). Perspectives on mentoring support during teaching practicum in local and international settings. International Journal of Learning, Teaching and Educational Research, 19(5), 336-351. https://doi.org/10.26803/ijlter.19.5.21

Abdullah, S., \& Akhter, J. (2015). Uses of Humor in an English Language Class. Retrieved from https://www.researchgate.net/publication/283719469_Uses_of_Humour_in_an_English_Language_Class

Academy of Diversity and Inclusive Education. (2012). Transformative Education. Retrieved from https://www.ius.edu/diversity/files/transformative-education.pdf

Adebola, O. O., Tsotetsi, C. T., \& Omodan, B. I. (2020). Enhancing students' academic performance in university system: The perspective of supplemental instruction. International Journal of Learning, Teaching and Educational Research, 19(5), 217-230. https://doi.org/10.26803/ijlter.19.5.13

Albite, R. (2019). A case study of topnotchers' preparations and contributory attributes in passing the licensure examination for teachers. Southeastern Philippines Journal of Research and Development, 24(2), 55-78.

Amanah, F. S. (2019). The effectiveness of humor used by teachers in teaching English towards second language learners. International Journal of Humanities, Philosophy and Language, 2(8), 116-127. https://doi.org/10.35631/ijhpl.28009

Amanonce, J. T., \& Maramag, A. M. (2020). Licensure examination performance and academic achievement of Teacher Education graduates: A search for congruity. International Journal of Evaluation and Research in Education, 9(3), 510-516. Retrieved from http://ijere.iaescore.com/index.php/IJERE/article/view/20614 
American Institute for Learning and Human Development. (2015). Multiple Intelligences. Retrieved from http://www.institute4learning.com/multiple_intelligences.php

Anwar, D. (2011). Patience Maybe the Most Important. Retrieved from http://schoolofeducators.com/2011/06/patience-may-be-the-most-important/

Aquino, A., \& Balilla, L. (2015). Pre-service teachers' licensure examination plans and content knowledge. Asia Pacific Journal of Education, Arts and Sciences, 2(2), 110-116.

Aquino, J. B. \& Nool, N. R. (2018). The Use of Edmodo with Journal Writing in Teaching Mathematics. Paper presented at the In-House Review of Completed Researches, Tarlac State University, Tarlac City. Retrieved from https://www.academia.edu/43388441/

Balagtas, M. U., \& Gerundio, M. G. (2014). Exploring formula for success in Teachers' Licensure Examination in the Philippines. Educational Measurement and Evaluation Review, 5(1), 104-117. Retrieved from https://ejournals.ph/article.php?id=6548

Balanquit, E. P., Ladia, M. A. P., Embesan, S. A., \& Legaspi, Y. S. (2018). The effect of remediation on the performance in retention examination of underachieving prospective secondary teachers. The Upland Farm Journal, 25(1), 15-28.

Bansiong, A. J. (2019). Entry-to-exit academic variables as predictors of BLEPT ratings. The Normal Lights, 13(2), 201-224. Retrieved from http://po.pnuresearchportal.org/ejournal/index.php/normallights/article/view/1392/424

Barros, S., \& Elia, M. F. (1997). Physics teacher's attitudes: How do they affect the reality of the classroom and models for change? Connecting Research in Physics Education with Teacher Education. Retrieved from https://www.univie.ac.at/pluslucis/Archiv/ICPE/D2.html

Bean, T. W., \& Stevens, L. P. (2002). Scaffolding reflection for preservice and inservice teachers. Reflective Practice, 3(2), 205-218. https://doi.org/10.1080/14623940220142343

Black, J. E. (2006). The Theoretical Base for Humor in the Classroom. Retrieved from https://www.academia.edu/261592/The_Theoretical_Base_for_Humor_in_the_Classroom

Blumberg, P. (2015). Learner-Centered Teaching. Retrieved from http://www.usciences.edu/teaching/Learner-Centered/

Bohman, J. (2005). Critical Theory. Retrieved from https://plato.stanford.edu/entries/critical-theory/

Bolton, R. (2005). Habermas' Theory of Communicative Action. Retrieved from http://web.williams.edu/Economics/papers/Habermas.pdf

Butin, D. W. (2006). The limits of service-learning in higher education. The Review of Higher Education, 29(4), 473-498. https://doi.org/10.1353/rhe.2006.0025

Cahapay, M. B. (2020). Probing the Differences Caused by Cognitive Variables on LET Performance: An Embedded Mixed Method Study. International Journal of Learning, Teaching and Educational Research, 19(4), 188-205. https://doi.org/10.26803/ijlter.19.4.12

Callena, E., Gabales, B., Tutor, R., Villanueva, S., Gonzales, C., de Vera, A., ... Pantaleon, A. (2019). Predictors of passing probability in licensure examination for selected programs in the University of Southeastern Philippines. Southeastern Philippines Journal of Research and Development, 24(1), 1-16.

Carrington, S., \& Selva, G. (2010). Critical social theory and transformative learning: Evidence in pre-service teachers'service-learning reflection logs. Higher Education Research \& Development, 29(1), 45-57. https://doi.org/10.1080/07294360903421384

Cepeda, Mara (2017). CHED eyes possible closure of weak schools for teachers. Retrieved from https://rappler.com/nation/ched-possible-closure-worst-teacher-education-institutions

Chan-Rabanal, G. (2016). Academic achievement and LET performance of the bachelor of elementary education graduates, University of Northern Philippines. International Journal of Scientific and Research Publications, 6(6), 455-461.

Chavez, M. (2016). Advantages of School Field Trip. Retrieved from https://education-teaching-careers.knoji.com/advantages-of-school-field-trips/

Christie, M., Carey, M., Robertson, A., \& Grainger, P. (2015). Putting transformative learning theory into practice. Australian Journal of Adult Learning, 55(1), 9-30. Retrieved from 
http://files.eric.ed.gov/fulltext/EJ1059138.pdf

CMO No. 30, s. 2004. Revised Policies and Standards for Undergraduate Teacher Education Curriculum.

CMO No. 75, s. 2017. Policies, Standards and Guidelines for Bachelor of Secondary Education (BSEd).

Cooper, S. (2014). Jack Mezirow: Transformational Learning. Retrieved from http://www.lifecircles-inc.com/Learningtheories/humanist/mezirow.html

Corpuz, B. B. et al. (2006). Principles of Teaching. Philippines: Lorimar Publishing.

Corpuz, N. B. (2015). Listening to Youth: An intervention. International Journal of Organizational Innovation, 7(4), 129-137.

Corpuz, N. B. (2017). Development and validation of Guidance in Action for the Betterment of All Youth (GABAY) sourcebook. The Upland Farm Journal, 25(1), 36-47.

Corpuz, N. B., David, S. M. O., Mendoza, J. P., \& Punzalan, J. Y. (2017). Validation of the general and professional education areas of the college of education's retention examination. University of the Visayas-Journal of Research, 11(1), 69-76. https://doi.org/10.5281/zenodo.2445758

Corradetti, C. (2015). The Frankfurt School and Critical Theory. Internet Encyclopedia of Philosophy. Accessed from http://www.iep.utm.edu/frankfur

Dagdag, J. D., Sarmiento, C. S., \& Ibale, J. C. (2017). Examining the factors of licensure examination for teachers performance for program strategy enhancement. Asia Pacific Journal of Multidisciplinary Research, 5(4), 34-39.

Daluba, N. E. (2013). Effect of demonstration method of teaching on students' achievement in agricultural science. World Journal of Education, 3(6), 1-7. https://doi.org/10.5430/wje.v3n6p1

Darling-Hammond, L., \& Bransford, J. (Eds.) (2005). Preparing teachers for a changing world: What teachers should learn and be able to do. San Francisco: Jossey Bass, Inc.

De Dios, A. (2012). Education for Life and Work: Developing Transferable Knowledge and Skills in the 21st Century. Retrieved from http://www.philippinesbasiceducation.us/2012/07/education-for-life-and-work-developing.html

DeLeon, A. P., \& Ross, E. W. (Eds.). (2010). Critical theories, radical pedagogies, and social education: New perspectives for social studies education. Rotterdam, The Netherlands: Sense. https://doi.org/10.1163/9789460912788

Department of Education. (2012). $\mathrm{K}$ to 12 ToolKit, 21st Century Skills. Retrieved from http://www.gov.ph/downloads/2012/201209-K-to-12-Toolkit.pdf

Department of Education. (2013). $K$ to 12 Curriculum Guide. Retrieved from http://www.deped.gov.ph/k-to-12/curriculum-guides

Department of Education. (2015). Positive Discipline in Everyday Teaching: A Primer for Filipino Teachers. Retrieved from http://www.deped.gov.ph/sites/default/files/page/2016/POSITIVE\%20DISCIPLINE\%20IN\% 20EVERYDAY\%20TEACHING\%20-\%20A\%20Primer\%20for\%20Filipino\%20Teachers.pdf

Desimone, L. M., Porter, A. C., Garet, M. S., Yoon, K. S., \& Birman, B. F. (2002). Effects of professional development on teachers' instruction: Results from a three-year longitudinal study. Educational Evaluation and Policy Analysis, 24(2), 81-112. https://doi.org/10.3102/01623737024002081

Doğan, S., \& Yurtseven, N. (2018). Professional learning as a predictor for instructional quality: A secondary analysis of TALIS. School Effectiveness and School Improvement, 29(1), 64-90. https://doi.org/10.1080/09243453.2017.1383274

Educational Broadcasting Corporation. (2004). What is Constructivism? Retrieved from http://www.thirteen.org/edonline/concept2class/constructivism

Elias, M. J. (2015). Using Humor in the Classroom. Retrieved from https://www.edutopia.org/blog/using-humor-in-the-classroom-maurice-elias

Embesan, S. A. (2004). Effectiveness of Math journals in teaching algebra to freshman education students of Tarlac State University. Education Journal, 5, 52-55.

Embesan, S. A. (2014). Mathematical Competencies of Prospective Mathematics Teachers. Paper presented at the 
In-House Review of Completed Researches, Tarlac State University. Retrieved from https://www.academia.edu/43293598/

Esmeralda, A. B., \& Perez-Espinosa, J. (2015). Teacher education graduates' performance as predictor of licensure examination for teachers results. JPAIR Multidisciplinary Research, 21(1). https://doi.org/10.7719/jpair.v21i1.330

Experiential Learning Courses Handbook. (2014). Higher Education Development Center: Quezon City Philippines.

Facun, R. D., \& Nool, N. R. (2012). Assessing the Number Sense of Grade 6 Pupils. Paper presented at International Conference on Education and Management Innovation, Singapore. Retrieved from http://www.ipedr.com/vol30/58-ICEMI\%202012-M10058.pdf

Fehintola, J. (2014). Teachers' characteristics as correlates of students' academic performance among secondary school students in Saki-west local government area of Oyo state. Journal of Educational and Social Research, 4(6), 459-468. https://doi.org/10.5901/jesr.2014.v4n6p459

Ferrer, R. C., Buted, D. R., \& Ferrer, I. C. (2015). Performance of BSEd science graduates in licensure examination for teachers: basis for a regression model. Asia Pacific Journal of Multidisciplinary Research, 3(5), 1-6.

Finley, T. (2014). 4 Things Transformational Teachers Do. Retrieved from https://www.edutopia.org/blog/big-things-transformational-teachers-do-todd-finley

Freeman, J., Simonsen, B., Briere, D. E., \& MacSuga-Gage, A. S. (2014). Pre-service teacher training in classroom management: A review of state accreditation policy and teacher preparation programs. Teacher Education and Special Education, 37(2), 106-120. https://doi.org/10.1177/0888406413507002

Galenzoga, D. M. (2016). Accreditation as a predictor for success in licensure examinations of state universities and colleges in Eastern Visayas. International Journal of Interdisciplinary Research and Innovations, 4(1), 101-105.

Garcia, H. (2010). Qualities of a Physical Education Teacher. Retrieved from http://www.ehow.com/info_7848031_qualities-physical-education-teacher.html

Guerriero, S. (2013). Teachers' pedagogical knowledge and the teaching profession: Background report and project objectives. Better Policies for Better Lives, 1-7. Retrieved from http://www.oecd.org/edu/ceri/Background_document_to_Symposium_ITEL-FINAL.pdf

Guilherme, M. (2010). Is there a Role for Critical Pedagogy? Retrieved from https://www.henryagiroux.com/publications.htm

Guo, S. C. (2011). Impact of an out-of-class activity on students' English awareness, vocabulary, and autonomy. Language Education in Asia, 2(2), 246-256. https://doi.org/10.5746/LEiA/11/V2/I2/A07/Guo

Gutierrez, N. P. (2016). Level of accreditation and board performance of the colleges of nursing in the National Capital Region. International Education \& Research Journal, 2(5), 21-29.

Harrison, J. L. (2011). Instructor transformational leadership and student outcomes. Emerging Leadership Journeys, 4(1), 91-119. Retrieved from www.researchgate.net/profile/Janelle_Harrison/publication/268421953

Harvey, L. (1990). Critical Social Research. London: Unwin Hyman. Retrieved from https://www.qualityresearch international.com/csr/CSR\%20Basics\%20(1990\%20published\%20original\%20version).pdf

Hong, S. (2020). Teachers' instructional components of warm-up rehearsal in elementary school chorus in South Korea. International Journal of Learning, Teaching and Educational Research, 19(4), 62-77. https://doi.org/10.26803/ijlter.19.4.5

Hu, C., \& Fyfe, V. (2010). Impact of a new curriculum on pre-service teachers' technical, pedagogical and content knowledge (TPACK). Proceedings Ascilite Sydney, 184-189. Retrieved from http://www.ascilite.org/conferences/sydney10/procs/Chun_Hu-concise.pdf

Hudson, M. (2014). Education for Change: Henry Giroux and Transformative Critical Pedagogy. Retrieved from http://www.solidarity-us.org/node/1734

Huong, V. T. M., Tung, N. T. T., Hong, T. T. M., \& Hung, D. H. (2020). Partnerships between teacher education universities and schools in practicum to train pre-service teachers of Vietnam. International Journal of Higher Education, 9(5), 134-152. https://doi.org/10.5430/ijhe.v9n5p134

Jafri, N., Manaf, U. K. A., \& Razali, F. (2020). Exploring teachers' pedagogical practices in teaching Mandarin as a 
foreign language in MARA educational institutions, Malaysia. International Journal of Learning, Teaching and Educational Research, 19(6), 76-94. https://doi.org/10.26803/ijlter.19.6.5

James, N. P. (2014). Golden rules for engaging students in learning activities. Edutopia. Retrieved from https://www.edutopia.org/blog/golden-rules-for-engaging-students- nicolas-pino-james

Jessop, S. (2012). Critical Theory and Education. Retrieved from https://www.philosophy-of-education.org/pdf

Kalaw, M. T. B. (2017). Trend of De La Salle Lipa Education graduates' performance in the licensure examination for teachers. International Journal of Evaluation and Research in Education, 6(2), 138-149. https://doi.org/10.11591/ijere.v6i2.7592

Khabanyane, K. E., Maimane, J. R., \& Ramabenyane, M. J. (2014). A critical reflection on transformative learning as experienced by student-teachers during school-based learning. Mediterranean Journal of Social Sciences, $5(27$ P1), 452. https://doi.org/10.5901/mjss.2014.v5n27p452

Kitchenham, A. (2008). The evolution of John Mezirow's transformative learning theory. Journal of Transformative Education, 6(2), 104-123. https://doi.org/10.1177/1541344608322678

Korobkin, D. (1988). Humor in the classroom: Considerations and strategies. College Teaching, 36(4), 154-158. https://doi.org/10.1080/87567555.1988.10532139

Ladia, M. A. P. (2014). Analysis of the LET performance of centers of excellence and centers of development for teacher education: Implications to policy, practice and research. International Journal of Engineering Research and Management, 1(6), 210-220. Retrieved from https://www.ijerm.com/download_data/IJERM010979.pdf

Ladia, M. A. P. (2015). The Effectiveness of the Flipped Classroom Pedagogy in Promoting Student's Critical Thinking. Paper presented at the In-House Review of Completed Researches, Tarlac State University, Tarlac City.

Ladia, M. A. P., \& Nool, N. R. (2011). Centers of Excellence and Centers of Development for Teacher Education: Their Contribution to the Elementary Teacher Force. Paper presented at the In-House Review of Completed Researches, Tarlac State University, Tarlac City. Retrieved from https://www.academia.edu/43328938/

Ladia, M. A. P., \& Nool, N. R. (2012). Analysis of the LET Performance of State Universities and Colleges in Region III. Paper presented at the In-House Review of Completed Researches, Tarlac State University, Tarlac City. Retrieved from https://www.academia.edu/7963956/

Ladia, M. A. P., \& Nool, N. R. (2017). Performance in the Licensure Examination of Teacher Education Institutions in Central Luzon. Paper presented at the In-House Review of Completed Researches, Tarlac State University, Tarlac City. Retrieved from https://www.academia.edu/42318602/

Lam, C. (2016). 11 Habits of an Effective Teacher. Retrieved from www.edutopia.org/discussion/11-habits-effective-teacher

Lee, H. J. (2005). Understanding and assessing preservice teachers' reflective thinking. Teaching and Teacher Education, 21(6), 699-715. https://doi.org/10.1016/j.tate.2005.05.007

Littky, D., \& Grabelle, S. (2012). The Real Goals of Education. Retrieved from http://www.ascd.org/publications/books/104438/chapters/The-Real-Goals-of-Education.aspx

Liu, Y., \& Liao, W. (2019). Professional development and teacher efficacy: Evidence from the 2013 TALIS. School Effectiveness and School Improvement, 30(4), 487-509. https://doi.org/10.1080/09243453.2019.1612454

Lugo, J. (2009). Collaborative and Transformative Learning. Retrieved from http://newlearningenvironmentsnle.blogspot.com/2009/11/collaborative-and-transformative.html

Makam, A. (2012). Critical Reflection on Teaching and Learning. Retrieved from https://www.academia.edu/1620363/Critical_Reflection_on_Teaching_and_Learning

Malone, K. (2008). An Evidence Based Research Report on the Role of Learning Outside the Classroom for Children's whole development from Birth to Eighteen Years. School and Families, Wollongong, Australia. Retrieved from www.face-online.org.uk/docman/news/every-experience-matters/download

Mart, C. T. (2013). A passionate teacher: Teacher commitment and dedication to student learning. International Journal of Academic Research in Progressive Education and Development, 2(1), 437-442. Retrieved from http://www.hrmars.com/admin/pics/1658.pdf 
Masangkay, M. G. (2012). Effectiveness of Kodaly method as innovative strategy in teaching music. Education Journal, 13, 36-52.

Masangkay, M. G. (2018). Talent Engagement and Leadership Abilities of College of Education Faculty Members in State Universities and Colleges of Region III: Basis of a Teacher Management Program. Paper presented at the In-House Review of Completed Researches, Tarlac State University, Tarlac City, Philippines.

Mateo, J. (2017, October 4). Teacher performance in board exams worsening. The Philippine Star. Retrieved from https://www.pressreader.com/philippines/the-philippine-star/20171005/281694024986849

Mattesson, D. M., \& Freeman, D. K. (2006). The Role of Demonstration. Retrieved from https://www.rcowen.com/PDFs/ATBR\%20Ch\%202\%20for\%20website.pdf

McIntyre, T. (2014). Competitive vs. Cooperative Learning Formats. Retrieved from http://www.behavioradvisor.com/CoopLearning.html

McNeely, R. (2015). Using Humor in the Classroom. Retrieved from http://www.nea.org/tools/52165.htm

Mendoza, J. J. N. (2014). LET Performance of the BSEd Graduates of the Tarlac State University-College Education. Review of Social Studies, Law and Psychology, 8(2), 12-17.

Mendoza, J. P. (2015). Isang pagsasalin at pagsusuri sa mga piling maikling kwento [A translation and analysis of selected short stories]. Education Journal, 16, 64-74.

Mercado, R. M. (2018). Poetry as Instructional Strategy in Ooutcomes-Based Teaching-Learning in Professional Education Courses. Paper presented at the In-House Review of Completed Researches, Tarlac State University, Tarlac City.

Metzler, J., \& Woessmann, L. (2012). The impact of teacher subject knowledge on student achievement: Evidence from within-teacher within-student variation. Journal of Development Economics, 99(2), 486-496. https://doi.org/10.1016/j.jdeveco.2012.06.002

Meyer, K. (2012). Why Leaders Must be Readers. Retrieved from http://www.forbes.com/sites/85broads/2012/08/03/why-leaders-must-be-readers/\#4f5a19d46563

Mezirow, J. (1981). A critical theory of adult learning and education. Adult Education, 32(1), 3-24. https://doi.org/10.1177/074171368103200101

Mintz, S. (2015). Transformational Teaching. $\quad$ Retrieved from http://www.columbia.edu/cu/tat/pdfs/Transformational\%20Teaching.pdf

Mizerow, J. (2011). Fostering Critical Thinking in Adulthood. Retrieved from http://www.ln.edu.hk/osl/conference2011/output/breakout/4.4\%20\%5Bref\%5DHow\%20Critical\%20Reflection\%2 0triggers\%20Transformative\%20Learning\%20-\%20Mezirow.pdf

Mondal, P. (2015). 7 Important Factors that May Affect Teaching-Learning Process. Retrieved from http://www.yourarticlelibrary.com/learning/7-important-factors-that-may-affect-the-learning-process/6064/

Morales, S. P. (2015). Pagsusuri ng mga makabagong tulang Filipino tungo sa pagbuo ng mungkahing balangkas sa pagtuturo [Analysis of modern Filipino poems toward the development of a proposed outline in teaching]. Education Journal, 16, 29-63.

Muir, T., Allen, J. M., Rayner, C. S., \& Cleland, B. (2013). Preparing pre-service teachers for classroom practice in a virtual world: A pilot study using Second Life. Journal of Interactive Media in Education, 2013(1), 1-17. https://doi.org/10.5334/2013-03

National Center for Education Statistics. (1999). Teacher Quality: A Report on the Preparation and Qualifications of Public School Teachers. Retrieved from https://nces.ed.gov/surveys/frss/publications/1999080/index.asp?sectionid=4

Neuliep, J. W. (1991). An examination of the content of high school teachers' humor in the classroom and the development of an inductively derived taxonomy of classroom humor. Communication Education, 40(4), 343-355. https://doi.org/10.1080/03634529109378859

Nool, N. R., \& Ladia, M. A. P. (2017). Trend of performance in the licensure examination of teacher education institutions in Central Luzon, Philippines. International Journal of Applied Engineering Research, 12(24), 15734-15745. Retrieved from http://www.ripublication.com/ijaer17/ijaerv12n24_248.pdf 
Nool, N. R. (2009). Development and Validation of an Improvised Manipulative Material as Remediation Device in Teaching Addition of Integers. Paper presented at the In-House Review of Completed Researches, Tarlac State University, Tarlac City. Retrieved from https://www.academia.edu/42318877/

Nool, N. R. (2011). Metacognitive Processes of Prospective Mathematics Teachers during Problem Solving. Paper presented at the Annual In-House Review of Completed Researches, Tarlac State University, Tarlac City. Accessed from https://www.academia.edu/

Nool, N. R. (2012). Mathematics Engagement and Performance of Secondary Student i n Classroom Setting Employing Understanding by Design (UBD) Framework. Paper presented at the In-House Review of Completed Researches, Tarlac State University, Tarlac City. Retrieved from https://www.academia.edu/43324765/

Nool, N. R. (2018). Analysis of the Licensure Examination for Teachers (LET) performance of Bachelor of Elementary Education graduates: Basis for Enhancement in Curriculum and Instruction. Paper presented at the In-House Review of Completed Researches, Tarlac State University, Tarlac City. Retrieved from https://www.academia.edu/42315867/

Nool, N. R. (2018). Development and Validation of a Worktext in Fundamentals of Mathematics. Paper presented at the In-House Review of Completed Researches, Tarlac State University, Tarlac City, Philippines. Retrieved from https://www.academia.edu/43331824/

Nool, N. R., Balanquit, E. P., \& Ladia, M. A. P. (2018). Influence of Faculty Members' Educational Attainment on Graduates' LET Performance among State Universities and Colleges. Paper presented at the In-House Review of Completed Researches, Tarlac State University, Tarlac City. Retrieved from https://www.academia.edu/43969302/

Nool, N. R., Ladia, M. A. P., Balanquit, E. P., \& Corpuz, N. B. (2018). Does Accreditation Status Matter? Evidence on the LET Performance of State Universities and Colleges. Paper presented at the In-House Review of Completed Researches, Tarlac State University, Tarlac City.

Nool, N. R., Ladia, M. A. P., Corpuz, N. B., \& Embesan, S. A. (2017). Exploring the Validity of TSU College Admission Test in Predicting Graduates' LET Performance. Paper presented at the In-House Review of Completed Researches, Tarlac State University, Tarlac City. Retrieved from https://www.academia.edu/42318279/

Official Gazette. (2012). Trainers and teachers undergo training for $\mathrm{K}$ to 12 roll out in June. Retrieved from http://www.gov.ph/2012/05/16/trainers-and-teachers-trained-for-k-to-12-rollout-in-june/

Ormrod, J. E. (2014). How Motivation Affects Learning and Behavior. Retrieved from http://www.education.com/reference/article/motivation-affects-learning-behavior/

Ortilla, M. (2015). Problems Hounding K-to-12 program (Part 1): Undelivered Books. Retrieved from http://cnn philippines.com/investigative/2015/06/25/Problems-hounding-K-to-12-program-Part-1-Undelivered-books.html

Özdemir, N. (2020). How to improve teachers' instructional practices: The role of professional learning activities, classroom observation and leadership content knowledge in Turkey. Journal of Educational Administration. https://doi.org/10.1108/JEA-10-2019-0189

Pal, R., Kar, S., Zaman, F. A., Jha, D. K., \& Pal, S. (2012). Assessment of impact of small group teaching among students in community medicine. Indian Journal of Community Medicine: Official Publication of Indian Association of Preventive \& Social Medicine, 37(3), 170-173. https://doi.org/10.4103/0970-0218.99920

Parrett, W. H., \& Budge, K. M. (2020). Turning high-poverty schools into high-performing schools (2nd ed.). Alexandria, Virginia: Association for Supervision \& Curriculum Development.

Pascua, J., \& Navalta, J. (2011). Determinants of LET performance of the teacher education graduates in a state university. JPAIR Multidisciplinary Journal, 6(1), 90-102. https://doi.org/10.7719/jpair.v6i1.138

Poyraz, C., \& Usta, S. (2013). Investigation of preservice teachers' reflective thinking tendencies in terms of various variances. International Journal on New Trends in Education and Their Implications, 4(2), 126-136. Retrieved from http://www.ijonte.org/FileUpload/ks63207/File/12.poyraz.pdf

Punzalan, J. Y. (2019). Career Success and Competency Skills of Bachelor of Secondary Education-Physical Science Graduates. Paper presented at the In-House Review of Completed Researches, Tarlac State University, Tarlac City. 
Qadhi, S., Hendawi, M., Ghazi, E., Ghazi, I., Al-Dosari, N., \& Du, X. (2020). The impact of a teacher preparation programs on professional teaching competencies - female novice teachers' perspectives. International Journal of Learning, Teaching and Educational Research, 19(1), 118-135. https://doi.org/10.26803/ijlter.19.1.7

Quiambao, C. G., \& Punzalan, J. Y. (2019). Development and validation of infographics based on the least mastered competencies in Physics. International Journal of Recent Technology and Engineering, 8(1C2), 352-357. Retrieved from https://www.ijrte.org/wp-content/uploads/papers/v8i1C2/A10560581C219.pdf

Quiambao, D. T., Baking, E. G., Buenviaje, L. B., Nuqui, A. V., \& Cruz, R. C. (2015). Predictors of board exam performance of the DHVTSU College of Education graduates. Journal of Business \& Management Studies, 1(1), 1-4.

Rahiem, M. D. H., Abdullah, N. S. M., \& Krauss, S. E. (2020). Moral education through dramatized storytelling: Insights and observations from Indonesia kindergarten teachers. International Journal of Learning, Teaching and Educational Research, 19(3), 475-490. https://doi.org/10.26803/ijlter.19.3.26

Ravitch, D. (2012). Without Content Mastery, the Teacher is a Goner. Retrieved from https://dianeravitch.net/2012/07/12/without-content-mastery-the-teacher-is-a-goner/

Reflective Thinking. (2012). What is Reflective Thinking? Retrieved from http://www.hawaii.edu/intlrel/pols382/Reflective\%20Thinking\%20-\%20UH/reflection.html

Republic Act 7836. An Act to Strengthen the Regulation and Supervision of the Practice of Teaching in the Philippines and Prescribing a Licensure Examination for Teachers and for Other Purposes. Retrieved from https://www.chanrobles.com/republicactno7836.htm

Robert Wood Johnson Foundation. (2008). Critical Theory Paradigms. Retrieved from http://www.qualres.org/HomeCrit-3518.html

Robert Wood Johnson Foundation. (2008). Maximum Variation Sampling. Retrieved from http://www.qualres.org/HomeMaxi-3803.html

Rosales, A., Arugay, Y., Divina Gracia, C., \& Palaganas, E. (2014). Analytical study of the nurses licensure examination performance of graduates of Philippine colleges of nursing. Philippine Journal of Nursing, 84(1), 4-20.

Ruben, E. F. (2014). Correlates of performance on the licensure examination of selected public and private teacher education institutions. International Journal of Education and Research, 2(8), 167-176.

Ryan, G. W., \& Bernard, H. R. (2000). Techniques to identify themes in qualitative data. Handbook of Qualitative Research (2nd ed). Thousand Oaks, CA: Sage Publications. Retrieved from http://www.acrn.eu/cambridge/downloads/files/QualitativeCoding.pdf

Salas, R. C. (2018). Assessment of the Qualifications and Competencies of the Technology and Livelihood Education Faculty in Teacher Education Institutions. Paper presented at the In-House Review of Completed Researches, Tarlac State University, Tarlac City, Philippines.

Samson, P. X. V. (2016). Development and Validation of an Interactive Computer Aided Instructional Software on Complex Numbers. Paper presented at the National Conference on Research in Teacher Education, Philippine Normal University, Manila, Philippines. Retrieved from https://www.academia.edu/43293136/

Seiler, R. (1988). Human Communication in the Critical Theory Tradition. Retrieved from http://people.ucalgary.ca/ rseiler/critical.htm

Sela-Shayovitz, R., \& Finkelstein, I. (2020). Self-Efficacy in teaching multicultural students in academia. International Journal of Higher Education, 9(1), 159-167. https://doi.org/10.5430/ijhe.v9n1p159

Shiyab, S. (2009). Pedagogical effect of humor on teaching. DigitalStream Proceedings. Retrieved from https://www.academia.edu/698395/Pedagogical_Effect_of_Humor_on_Teaching

Shulman, L. S. (2015). What Teachers Should Know and be Able to Do. Retrieved from http://www.nbpts.org/sites/default/files/what_teachers_should_know.pdf

Slavich, G. M., \& Zimbardo, P. G. (2012). Transformational teaching: Theoretical underpinnings, basic principles, and core methods. Educational Psychology Review, 24(4), 569-608. https://doi.org/10.1007/s10648-012-9199-6

Smith, L. (2014). Public Speaking and Critical Thinking Skills. Retrieved from http://integrative.gmu.edu/courses/1316/course_sections/16666

Smoot, B. (2013). Passion and Awareness: What Great Teachers Have in Common. Retrieved from 
https://www.higheredjobs.com/blog/postDisplay.cfm?post=412

Solis-Foronda, M. (2017, August). Predictors of licensure examination for teachers (LET) performance: A mediation analysis. Proceedings of the International Conference on Digital Technology in Education (pp. 74-78). https://doi.org/10.1145/3134847.3134863

Solomon, B. (2015). The Pygmalion Effect: Communicating High Expectations. Retrieved from https://www.edutopia.org/blog/pygmalion-effect-communicating-higher-expectations-ben-solomon

Sorensen, T. B., \& Robertson, S. L. (2019). Reframing teachers' work for global competitiveness: New global hierarchies in the governing of education. In K. J. Saltman \& A. J. Means (Eds), The Wiley Handbook of Global Educational Reform (pp.87-111). John Wiley \& Sons, Inc. https://doi.org/10.1002/9781119082316.ch5

Stemler, S. (2000). An overview of content analysis. Practical Assessment, Research, and Evaluation, 7(1), 1-17. https://doi.org/10.7275/z6fm-2e34

Tan, C. S. (2016). Impact of review on the performance of graduates in the licensure examination for teachers, 2012-2014. e-Proceedings of the 4th Global Summit on Education, 64-73.

Tangen, D., Mercer, K. L., Spooner-Lane, R., \& Hepple, E. (2011). Exploring intercultural competence: A service-learning approach. Australian Journal of Teacher Education, 36(11), 62-72. https://doi.org/10.14221/ajte.2011v36n11.2

Teaching Council. (2011). Initial teacher education: Criteria and guidelines for programme providers. Maynooth: Teaching Council. Retrieved from http://www.teachingcouncil.ie/en/Publications/Teacher-Education/Initial-Teacher-Education-Criteria-and-Guidel ines-for-Programme-Providers.pdf

Thomas, J., Nelson, J., \& Silverman, S. (2010). Explore four methods for collecting qualitative research. Research Methods in Physical Activity (6th ed.). Retrieved from http://www.humankinetics.com/excerpts/excerpts/explore-four-methods- forcollecting-qualitative-research

Tsiplakides, I., \& Keramida, A. (2010). The relationship between teacher expectations and student achievement in the teaching of English as a foreign language. English Language Teaching, 3(2), 22-26. https://doi.org/10.5539/elt.v3n2p22

Ulug, M., Ozden, M. S., \& Eryilmaz, A. (2011). The effects of teachers' attitudes on students' personality and performance. Procedia-Social and Behavioral Sciences, 30, 738-742. https://doi.org/10.1016/j.sbspro.2011.10.144

UNC Charlotte. (2008). Communicating High Expectations. Retrieved from http://teaching.uncc.edu/podcast/communicating-high-expectations

University of Washington. (2016). Engaging Students in Learning. Retrieved from http://www.washington.edu/teaching/ teaching-resources/engaging-students-in-learning/

Utemov, V. (2019). A comparative study of the qualities of school teachers and their teaching practice. ARPHA Proceedings, 1, 735-749. https://doi.org/10.3897/ap.1.e0698

Visco, D. (2015). Predictors of performance in the licensure examination for teachers of the graduates of higher education institutions in Abra. International Journal of Management Research and Business Strategy, 4(1), 181-191.

Walker, R. J. (2008). Twelve characteristics of an effective teacher: A longitudinal, qualitative, quasi-research study of in-service and pre-service teachers' opinions. Educational Horizons, 87(1), 61-68. Retrieved from https://www.jstor.org/stable/42923744

Weimer, M. (2008). Teaching Strategies for Transformative Learning. Retrieved from http://www.facultyfocus.com/articles/effective-teaching-strategies/teaching-strategies-for-transformative-learning I

Wormeli, R. (2016). Patience and Tenacious Teaching. Retrieved from https://www.amle.org/BrowsebyTopic/WhatsNew/WNDet/TabId/270/ArtMID/888/ArticleID/431/Patient-and-T enacious-Teaching.aspx

Yasin, R. M., Rahman, S., \& Ahmad, A. R. (2012). Framework for reflective learning using portfolios in pre-service


https://doi.org/10.1016/j.sbspro.2012.06.156 
Zeichner, K. (2010). Rethinking the connections between campus courses and field experiences in college-and university-based teacher education. Journal of Teacher Education, 61(1-2), 89-99. doi.org/10.1177/0022487109347671

Zhang, J., Kuusisto, E., \& Tirri, K. (2020). Same mindset, different pedagogical strategies: A case study comparing Chinese and Finnish teachers. International Journal of Learning, Teaching and Educational Research, 19(2), 248-262. https://doi.org/10.26803/ijlter.19.2.15

Zimmerman, T., Schmidt, L., Becker, J., Peterson, J., Nyland, R., \& Surdick, R. (2014). Narrowing the gap between students and instructors: A study of expectations. Transformative Dialogues: Teaching \& Learning Journal, 7(1), 1-18. Retrieved from http://www.kpu.ca/sites/default/files/ Transformative\%20Dialogues/ TD.7.1.8_Zimmerman_etal_Narrowing_the_Gap.pdf

\section{Copyrights}

Copyright for this article is retained by the author(s), with first publication rights granted to the journal.

This is an open-access article distributed under the terms and conditions of the Creative Commons Attribution license (http://creativecommons.org/licenses/by/4.0/). 